\title{
Female migration: A way out of discrimination?
}

\author{
Ilse Ruyssen ${ }^{\mathrm{a}, \mathrm{b}, *}$, Sara Salomone $\mathrm{e}^{\mathrm{a}, \mathrm{b}, \mathrm{c}, * *}$ \\ ${ }^{a}$ SHERPPA, Ghent University \\ ${ }^{b}$ IRES, Université Catholique de Louvain \\ ${ }^{c} U N U-C R I S$
}

\begin{abstract}
In light of the recent feminization of migration, we empirically explore to what extent worldwide female migration can be explained by perceived gender discrimination. Making use of unique individual level data, we track women's intention and preparation to migrate from 148 countries between 2009-2013 and disentangle how individual perceptions of gender discrimination can foster or impede female migration across countries. We perform extensive robustness checks to mitigate concerns about potential threats to identification posed by measurement error and unobservables. Our evidence indicates that women who do not feel treated with respect and dignity have a higher incentive to migrate abroad. The likelihood that these migration intentions are turned into actual preparations, however, depends on more traditional determinants such as household income, network effects and family obligations. Furthermore, we also show that more intense gender imbalances in economic and political opportunities prevent women from actually moving abroad.
\end{abstract}

Keywords: Female migration, Gender discrimination, Migration intentions, Selection model

\section{Introduction}

Gendered assessments of international migration processes are fairly recent both in the economic literature (Cobb-Clark, 1993; Cortes, 2015; Docquier et al., 2012; Kofman,

\footnotetext{
*Corresponding author, address: SHERPPA, Department of Economics, Ghent University, Tweekerkenstraat 2, B-9000 Gent, Belgium. Tel.: +3292644242; Fax: +3292643599.

**Address: UNU-CRIS, Potterierei 72, B-8000 Bruges, Belgium. Tel.: +321050471102.

Email addresses: Ilse.Ruyssen@Ugent.be (Ilse Ruyssen), Ssalomone@Cris.unu.edu (Sara Salomone)
} 
2000; Morrison et al. 2007; Zlotnik, 1990,1995) and comprehensive statistical datasets (Artuç et al., 2015; Docquier et al., 2009; Dumont et al., 2007). They are nonetheless essential for understanding female international migration (United Nations, 2004) and its implications for economic development. ${ }^{1}$ Our paper contributes to this strand of literature by empirically analyzing the role of perceived gender discrimination on female migration intentions and subsequent migration behavior using original individual level data compiled by the Gallup World Polls (GWP henceforth).

It is often put forward that female migration has now caught up to that of men, but the socalled 'feminization of migration' is not a new phenomenon (Jolly et al., 2005). ${ }^{2}$ Women already made up almost half of the migrant stock several decades ago and their numbers have been steadily growing, both in absolute terms and relative to the global migrant stock (Zlotnik, 2003). Without taking into consideration short-term and seasonal movements, women represent more than 48 percent of the 244 million international migrants in the world (United Nations, 2015). They outnumber men in developed countries with 51.5 percent while in developing countries they make up 45.6 percent of the total immigrant stock. Similar numbers apply for OECD and non-OECD countries (see Artuç et al., 2015). More importantly, women are more and more moving as independent or single migrants rather than as the wife, mother or daughter of male migrants (Oishi, 2002; Pedraza,

\footnotetext{
${ }^{1}$ Empirical analyses on the role of women related to economic outcomes can be found among others in Duflo and Udry (2004) who demonstrate how rainfall shocks that lead to higher yields of crops predominantly cultivated by women, shift expenditures towards food consumption; Sorensen (2004) who highlights the importance of female migrants in remitting money back home; Perkins et al. (2013) who stress the positive role of female presidents on managing fractionalized countries; Behrman et al. (2014) who provide evidence on the role of women in human capital transmission to children; Gajvani and Zhang (2014) who investigate the effects of women on the provision of public goods such as water; and finally Doepke and Tertilt (2017) who show that targeting transfers to women may be beneficial or harmful to growth. For a more comprehensive critical overview of the link between female empowerment and economic development see Duflo (2012).

${ }^{2}$ To put it in the words of Babatunde Osotimehin, former executive director of the UN Population Fund: "La migration porte un visage humain, et c'est celui d'une femme." In a 2013 article in Le Monde, also a UN correspondent stated that "La féminisation de la migration n'est plus une simple tendance. Apparue au début des années 1990, elle est devenue une réalité croissante et incontournable" (see http://www.lemonde.fr/ameriques/article/2013/05/08/le-nouveau-visage-feminin-dela-migration_3173506_3222.html).
} 
1991). These cross-border movements are to an increasing extent determined by economic factors (Meierrieks and Renner, 2017; Sassen, 2003), with women being part of worker flows, moving on their own to become the principal wage earners for their families (United Nations, 2004). Yet they also continue to flee from conflict (Berhanu and White, 2000), famine, persecution, epidemics, soil degradation (Gray, 2012), natural disasters (Gray and Mueller, 2011) and other situations that affect their habitat, livelihood and security (United Nations, 2004). ${ }^{3}$

Among the non-economic factors explaining female migration, gender discrimination has recently proven to be of particular importance. Despite worldwide efforts to reduce gender disparities, in general, women continue to lag behind in terms of basic freedoms and opportunities, which might in turn have an impact on their migration behavior. The expected direction of the effect is however ambiguous (Hugo, 2000). On the one hand, restrictions on the role assigned to women may act as a push factor encouraging them to leave their home country (Black et al., 2004). On the other hand, it might be exactly those restrictions preventing them from leaving (Zachariah et al., 2001). Indeed, while hundreds of millions of women worldwide would be willing to leave their homelands and start a new life somewhere else, many of them may never actually set off because of economic and/or personal circumstances (Esipova et al., 2011), among which gender imbalances might play a role (see e.g. Chort, 2014).

Previous studies using macro data provide mixed evidence on the relationship between gender discrimination and women's migration behavior. Nejad (2013) and Nejad and Young (2014) investigate the effect of institutionalized gender inequality, proxied by the CIRI (Cingranelli-Richards) Human Rights Database (2014) women's rights index, on the high-skilled female migration rate. Their model predicts a non-linear impact of gender

\footnotetext{
${ }^{3}$ Focusing on the effects of non-economic determinants of both female and male migration, Loschmann and Siegel (2013) explore the influence of vulnerability on migration intentions within the context of Afghanistan and provide evidence that the most vulnerable households have the lowest likelihood to migrate. Cai et al. (2014) consider the impact of life satisfaction on the willingness to migrate abroad and find that at the individual level, subjective wellbeing appears even more important than objective income. This finding is also confirmed by Dustmann and Okatenko (2014) who show that migration intentions respond to individual wealth by alleviating budget constraints, especially in Sub-Saharan Africa and Asia. Yet, contentment with local amenities like security and public services are found to be even more important determinants shaping migration plans.
} 
inequality on the female brain drain ratio because of the adverse effect of gender inequality on the costs and benefits of migration, respectively. In the same vein, Baudassé and Bazillier (2014) implement a gravity model to test whether labor market discrimination should be considered either a push factor or a selection device for female migration. They reject the former hypothesis and conclude that - all else held constant - gender discrimination has a positive influence on the female brain drain. Bang and Mitra (2011) analyze the brain drain gap considering traditional controls as well as the quality of institutions and proxies for gender equality such as women's share of income, the fraction of women in parliament, the male-female literacy rate gap, the male-female secondary enrollment gap, the fertility rate and the female labor force participation rate. They find that a significant part of the brain drain gap can be explained by the disequilibrium in access to economic opportunities, captured by the fertility rate and differences in schooling and literacy. Ferrant and Tuccio (2015), on the other hand, make use of the Social Institutions and Gender Index (SIGI) developed by the OECD Development Centre, to provide empirical evidence on the relationship between gender inequality in social institutions and female South-South migration. They show that discriminatory social institutions in both origin and destination countries form an important determinant of female South-South migration.

Our study takes a new approach by making use of a subjective measure of gender discrimination to examine both migration intentions and further migration behavior regardless of destination. Unlike most studies disentangling the impact of gender imbalances on migration, we mostly rely on a micro level dataset and exploit the variation across individuals for a large number of countries (see also Bertoli and Ruyssen, 2016; Dustmann and Okatenko, 2014; Manchin and Orazbayev, 2016). The newly available GWP provide a unique and largely unexplored database on individual migration decisions as well as perceptions of gender discrimination and respondents' economic and demographic characteristics for 148 countries in the world between 2009 to 2013.

Our approach holds several advantages. First, by relying on individual perceptions besides aggregate macro indicators of gender discrimination, we capture more than pure gendered outcomes such as access to jobs, education, fertility and credit (see also Tuccio and Wahba, 2015) and measure women's experience with gender discrimination. As put forward by Kothari (2002), understanding why people migrate requires accounting for the complex interaction of individual agency and macro structures. In other words, by focusing on 
whether women feel treated with respect and dignity in their country of residence, we can identify the degree to which women can exercise agency depending on their sociocultural environment (De Haas, 2009). As such, the GWP prove ideal to assess and advance the existing macro evidence using an original micro-economic perspective.

Second, we are able to track a person's intention to migrate as well as whether this intention materializes. The decision to migrate has been shown to involve several steps, not all of them observable and measurable (Paul, 2011). A few earlier studies already recognized the distinction between migration intentions and actions (e.g. Cai et al., 2014; Dustmann and Okatenko, 2014; Hatton and Williamson, 2002), but data limitations generally prohibited a separate analysis of the different stages. A few exceptions make use of region or country-specific surveys to analyze both migration intentions and realizations (e.g. Chort, 2014, for Mexico; or van Dalen and Henkens, 2008, for the Netherlands). Chort (2014), for instance, uses micro data obtained from the two waves of the Mexican Family Life Survey panel (2002 and 2005-06) to study discrepancies between Mexicans' intention to migrate and their subsequent migration behavior. In fact, after having controlled for various macro shocks likely to affect the migration decision, she finds that women's probability to carry out their migration plans is systematically lower than men's and concludes that women's unrealized migration plans are due to gender specific costs and constraints.

We believe that an analysis of what drives the intention to migrate in itself may significantly contribute to our understanding of global migration dynamics. The Gallup database, nonetheless, also allows us to gain insight into how these migration intentions translate into actual plans and to explore to what extent perceived gender discrimination alongside traditional personal characteristics can foster or impede women's migration behavior. The empirical model that we bring to the data is a sample selection model in which migration intentions and preparations are jointly estimated using a Heckman probit approach which controls for common unobserved shocks affecting all inhabitants in the same way. Our estimation approach is exposed to the threats to identification posed by measurement error regarding our variable of interest as well as unobserved factors that influence both female migration behavior and perceptions of gender discrimination. We follow four distinct and complementary approaches to rule out the concern that estimated effect of perceived gender discrimination in determining migration behavior is driven by measurement error or omitted variables. 
Our empirical evidence reveals that perceived gender discrimination forms a strong and highly robust determinant of migration intentions, but it does not generally have an additional impact on subsequent migration behavior. Overall we find that women who do not feel treated with respect and dignity in their country have a stronger intention to move out. Perceived gender discrimination hence positively affects the size of potential female migration. Whether those intentions are subsequently turned into action is, however, determined by other more traditional factors such as household income, network effects or family obligations. Furthermore, we show that the likelihood that migration intentions are materialized is lower for women facing a larger gender gap in labor market participation disaggregated by level of education and rural versus urban residence.

From a development perspective, these results originally shed light on the role of international migration as an additional channel through which gender discrimination can influence origin economies which lag behind in terms of women's economic, political, social and cultural rights by pushing women abroad.

The remainder of the paper is structured as follows. Section 2 describes the data used in our empirical analysis obtained from the GWP as well as stylized facts on both migration and gender discrimination variables. Section 3 provides the empirical framework used to analyze the impact of perceived gender discrimination on migration behavior. Section 4 presents the empirical evidence from our benchmark model and it discusses threats to identification. Section 5 provides the main conclusions.

\section{Data and descriptives}

All the individual data of interest were obtained from the GWP, which have been documenting personal and household characteristics of respondents all over the world since 2005 as well as their opinions on a wide variety of topics. A typical Gallup survey interviews about a 1,000 randomly selected individuals within each country. ${ }^{4}$ The data are collected through telephone surveys in countries where the telephone coverage represents at least 80 percent of the population. In Central and Eastern Europe, as well as in developing regions, including much of Latin America, the former Soviet Union countries,

\footnotetext{
${ }^{4}$ In some large countries such as China, India and Russia as well as in major cities or areas of special interest, over-samples are collected resulting in larger total numbers of respondents.
} 
nearly all of Asia, the Middle East and Africa, on the other hand, an area frame design is used for face-to-face interviewing. The sampling frame represents the entire civilian, non-institutionalized population aged 15 and over covering the entire country including rural areas. ${ }^{5}$

Our sample contains 153,296 females with valid information on all the variables of interest used in the model, interviewed over the period 2009-2013 in 148 countries in the world. ${ }^{6}$ By 2013, the 148 countries represented about 97 percent of the worldwide population. In what follows, we explain in detail how the variables of interest have been constructed.

\subsection{Migration prospects}

The literature on migration intentions is small but growing (Becerra, 2012; Carling, 2002; Creighton, 2013; Drinkwater and Ingram, 2009; Dustmann and Okatenko, 2014; Jonsson, 2008; van Dalen et al., 2005a,b) and characterized by an ongoing discussion on whether migration aspirations actually signal a person's migration plans as opposed to pure wishful thinking (Manchin et al., 2014; van Dalen and Henkens, 2008). The intentions to migrate that we define in this paper are, however, stricter than mere migration considerations as used by e.g. Creighton (2013). Whereas the latter considers whether the respondent has thought about moving outside the locality or community where he or she lives in the future, the GWP use a stronger formulation which directly asks for the likely response under ideal conditions (Manchin et al., 2014). In fact, the GWP include two relevant questions capturing individual migration prospects: (i) "Ideally, if you had the opportunity, would you like to move permanently or temporarily to another country, or would you prefer to continue living in this country?" and (ii) "Have you done any preparation for this move (for example, applied for residency or visa, purchased a ticket, etc.)?", which is asked only

\footnotetext{
${ }^{5}$ That is with the exception of areas where the safety of the interviewing staff is threatened, scarcely populated islands in some countries, and areas that interviewers can reach only by foot, animal, or small boat.

${ }^{6}$ While most actual migration data concentrate on the population aged 25 and over, our sample covers also females aged 15-25. It could be argued that also younger women experience gender discrimination which might influence their migration behavior. Young girls being forced into early marriage, for instance, might have a higher willingness to leave their country but also a lower propensity to do so because they are at more risk of being held back. Excluding this age group does, however, not alter our main findings. The results are available upon request.
} 
to those who replied yes to question (i). ${ }^{7}$

Knowing what drives the intention to migrate allows to assess the subpopulation who would consider moving abroad across origins, which in itself yields interesting insights into future migration dynamics (see also Docquier et al., 2014; Dustmann and Okatenko, 2014). Nonetheless, to grasp to what extent migration intentions follow actual migration dynamics, Figures 1 and 2 plot the change in the number of actual migrants between 2000 and 2010 as a share of the population in each country against the share of respondents respectively intending or preparing to move out during our sample period. ${ }^{8}$ Overall correlations between actual migration movements and migration intentions or preparations amount to 0.19 and 0.27 , respectively, both statistically significant at 1 percent. Similar figures are obtained when the sample of respondents is restricted to natives only (i.e. 0.16 and 0.26 , respectively). In line with expectations, we thus find a positive though fairly small correlation between actual and potential migration. This is however not surprising:

\footnotetext{
${ }^{7}$ The questionnaire also has an intermediate question: "Are you planning to move permanently (temporarily) to another country in the next 12 (24) months, or not?", which we do not consider because contrary to its follow up question - a positive reply cannot separate vague ambitions from actual plans. Furthermore, it continues with the question "To which country would you like to move?". In this paper, we do not consider the destination dimension. Our goal is not to explore where women end up because of their own perception of gender discrimination but whether perceived gender discrimination can predict their migration behavior conditional on intending to move. While we acknowledge that knowing what determines the allocation of (female) emigrants across destinations and the role of (perceptions about) gender imbalances in potential destination countries would be equally relevant from a development point of view, addressing this issue would require a distinct empirical environment, such as the location choice model developed by McFadden (1974) in which the population of interest would consist only of those either intending or preparing to move abroad (see e.g. Bertoli and Ruyssen, 2016). Moreover, the GWP offer information on women's perception of gender discrimination only in their country of origin. They do not track women's assessment of the situation in the preferred destination country, so that only aggregate measures could be used. Therefore, we chose to focus on the emigration decision and leave the question of destination choice for future research.

${ }^{8}$ For the purpose of this comparison, we select only respondents aged 25 and over, compatible with actual migration figures. Futherfore, whenever we construct country aggregates, we weigh each individual observation by the relevant Gallup sample weight. These weights are designed to compensate for the low coverage of certain groups (by gender, race, age, educational attainment and region) in the whole population. Gallup assigns a weight to each respondent so that the demographic characteristics of the total weighted sample of respondents match the latest estimates of the demographic characteristics of the adult population available for the country (Gallup, 2012).
} 
in reality the translation of intended into actual migration is prevented by numerous personal circumstances such as health, finances or family obligations (Esipova et al., 2011) as well as institutional hurdles related to migration regulations restricting the free movement of people (Docquier et al., 2014). Regarding the discrepancy between migration preparations and actual migration, it is important to stress that whereas the first might encompass both legal and irregular migration plans, the latter is able to keep track only of legal migration (Docquier et al., 2014; Friebel et al., 2015; Mbaye, 2014).

Figure 1: Aggregate actual migration and migration intentions (females)

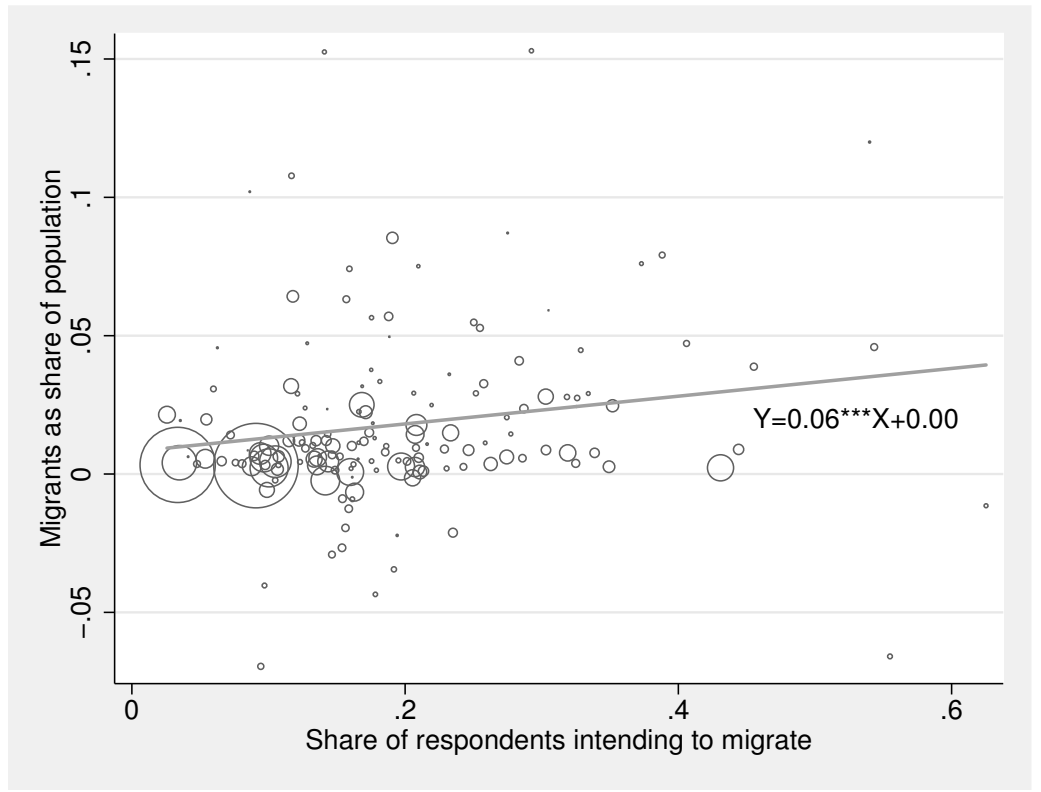

Notes: Authors' calculations based on the Gallup World Polls and the United Nations Database. Share of respondents intending to migrate denotes the share of female respondents claiming that they would be willing to move abroad when an opportunity arises. Migrants as share of population denotes the change in the number of female migrants between 2000 and 2010 by country of origin as a share of the female population in each origin country. The surface of each circle is proportional to the size of the native population residing in each country in 2000.

On average 16 percent of female respondents in our sample would be willing to migrate when an opportunity arises. Around 4 percent of them already made preparations to do so. These figures are slightly higher for men who appear to be both more willing to move abroad and more likely to actually do so. The gap between those who intend to migrate and those who are actively preparing to move is however larger for men, suggesting that women's reply to the question regarding migration intentions is more in line with actual 
Figure 2: Aggregate actual migration and migration preparations (females)

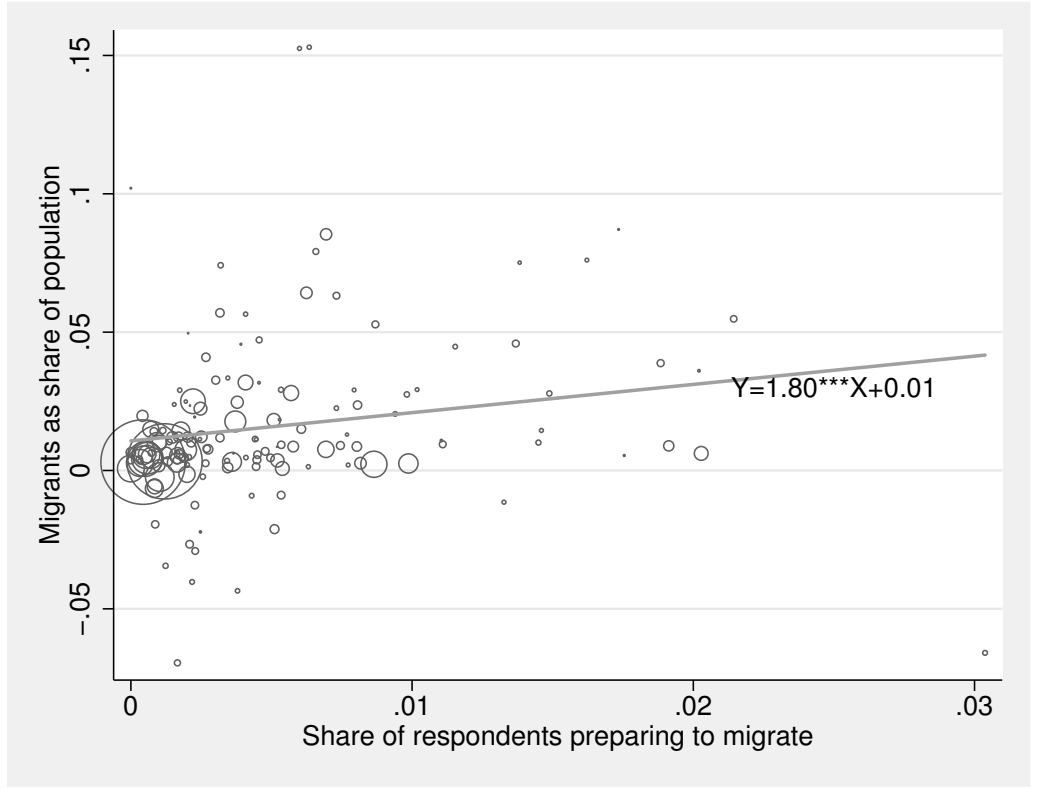

Notes: see Figure 1. Share of respondents preparing to migrate denotes the share of female respondents stating that they have made preparations to move abroad.

prospects than that of men (see also Chort, 2014). Young, high skilled and employed women have a higher chance of expressing an intention to move abroad, yet especially young Muslim women and those with a per capita household income in the 20 percent bottom percentile are preparing to do so in the near future. Females who are highly educated, secular and employed, finally, have a higher chance to turn their migration intentions into action.

Figures 3 and 4 respectively depict the shares of female respondents willing to move abroad and those who prepare to do so in the near future. Aggregate migration intentions appear particularly low in North America, South Asia, Oceania, the Middle East and Brazil. Higher shares are obtained in sub-Saharan Africa, Eastern Europe and other Latin American countries. The share of respondents claiming that they have started making preparations for their move abroad, on the other hand, appears especially large in South East Asia, Oceania, some sub-Saharan African countries, Central Asia and a number of Eastern European countries. 
Figure 3: Women's aggregate migration intentions by country

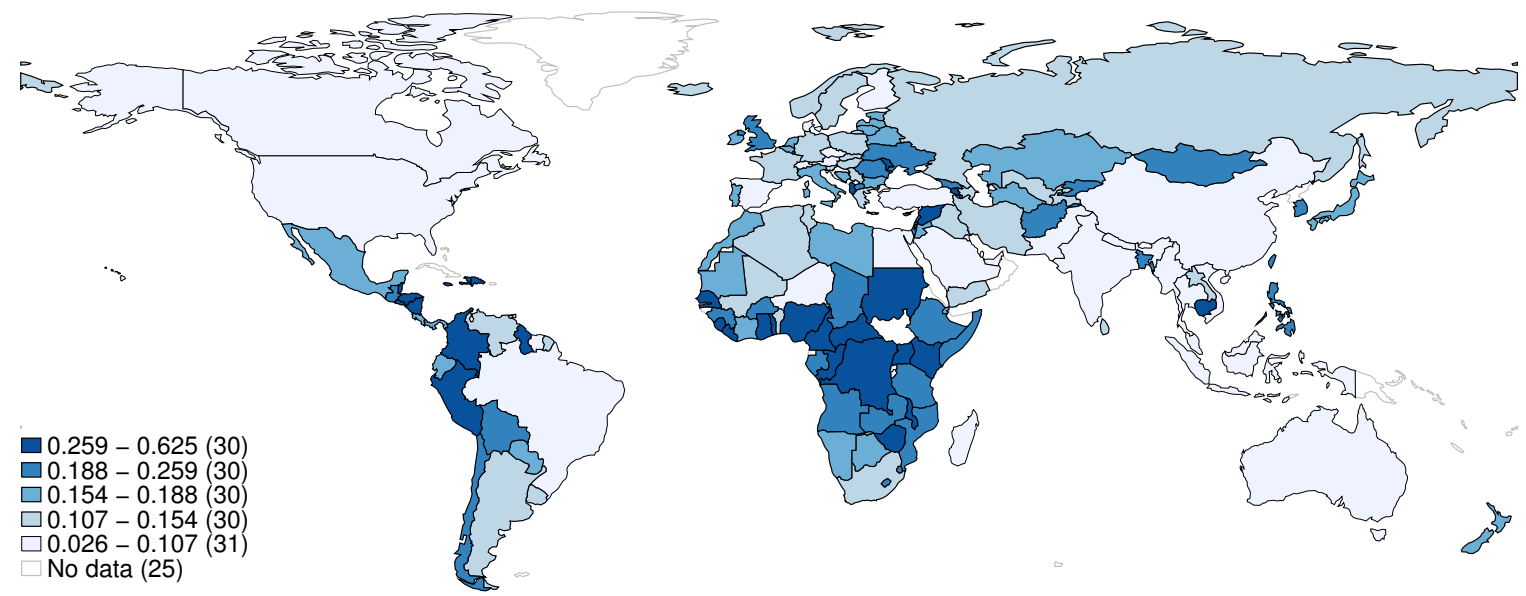

Source: Authors' calculations based on the Gallup World Polls.

Figure 4: Women's aggregate migration preparations by country

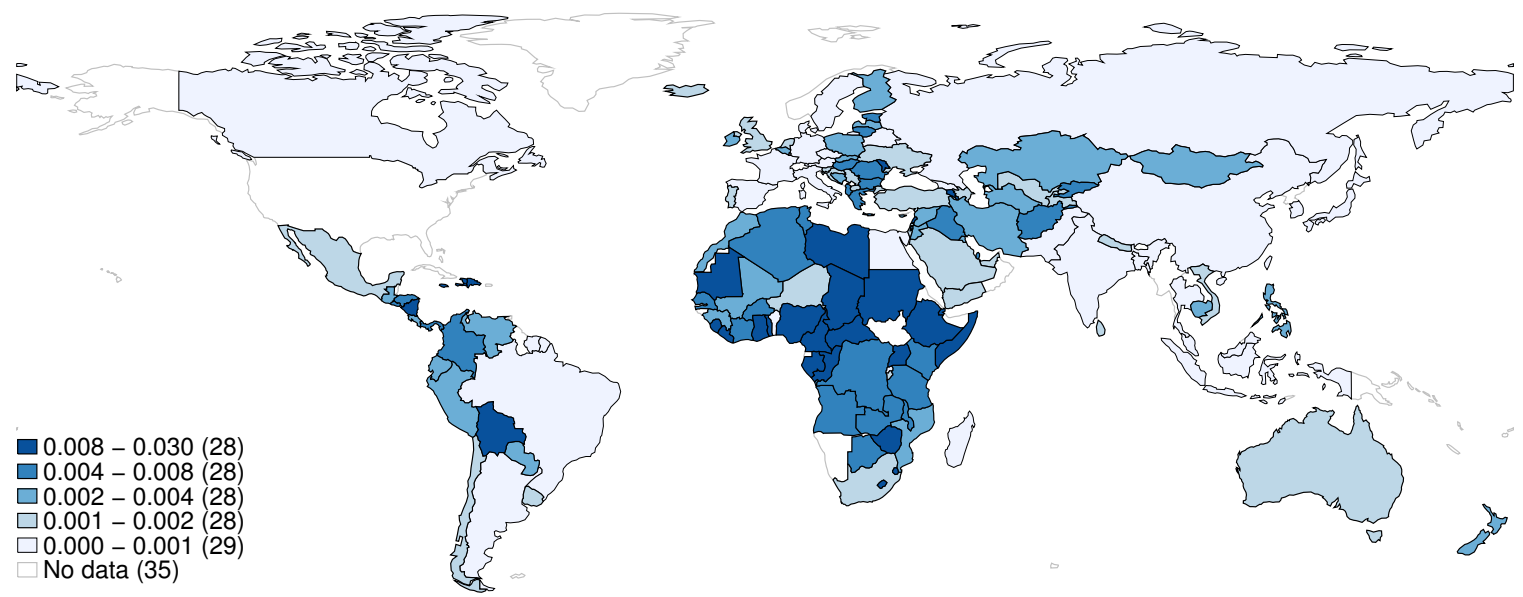

Source: Authors' calculations based on the Gallup World Polls.

\subsection{Gender discrimination}

The most comprehensive question on gender discrimination available in the GWP reads "Do you believe that women in this country are treated with respect and dignity, or not?", which is available for all countries in the sample between 2009 and 2013. A negative reply signals that a woman feels that females are discriminated (not treated with respect and dignity) in the country where she lives (coded as 1 and 0 otherwise). 
Ruyssen and Salomone (in press) explore in detail what this measure of perceived gender discrimination actually captures on the basis of statistical correlations with other individual indicators taken from the GWP as well as aggregate measures of gender discrimination frequently used in the literature. The two most relevant individual level indicators read "In this country, are men and women treated fairly at work, or not?" and "In your opinion, is domestic violence a serious problem for your country or not?", both available only for a subset of countries in our sample. In line with expectations, perceived gender discrimination appears negatively and significantly correlated with economic equality at work and significantly but positively correlated with the severity of domestic violence.

Subsequently, the aggregated variable of interest is compared with the Cingranelli-Richards Human Rights Dataset (2014) indicator on women's economic (Wecon) rights, the OECD Social Institutions and Gender Index, and the Country Policy and Institutional Assessments equality index from the World Bank. Pairwise correlations between these macro indicators and our aggregate measure of perceived gender discrimination indicate that women are more likely to feel treated with respect and dignity when they are entitled more economic rights, when they have higher access to credit, employment, and higher education and when adolescent fertility and early marriage are less widespread. Overall, it is concluded that the GWP measure of perceived gender discrimination refers to an unfair difference in treatment mainly related to economic issues and family heritages.

These correlations confirm that the GWP individual indicator of perceived gender discrimination measures similar aspects of gender imbalances as some of the macro indicators used in the literature. Yet, the fact that they do not perfectly correspond seems to confirm the idea that individual perceptions capture more than pure gendered outcomes. This is not surprising given that the former are influenced by personal characteristics such as the respondent's education level, religion, residence location (rural/urban) or her social environment (see e.g. Verloo, 2007). We believe that this individual perspective is exactly the strength of our dataset which allows for a detailed analysis of the impact of gender discrimination on the individual decision to migrate.

On average, 35 percent of female respondents state that women are not treated with respect and dignity in their country. This figure is even higher for women who express an intention to migrate, reaching 46 percent. In all but seven countries (Angola, Cambodia, Ethiopia, Honduras, Indonesia, Singapore and Yemen), women experience gender discrimination to be worse than men. The gap between female and male shares is on average 8 
percent, ranging from -5 to over 20 percent. In countries with a large gap, some men have either a lower awareness about the experiences of women or a different interpretation of respect, perhaps influenced by machismo attitudes (Gallup, 2012). The lowest shares of perceived gender discrimination are recorded for high skilled, non-religious females and women with a household income per capita in the top 20 percentile. Also for those employed and Muslim, average shares tend to be relatively lower. Younger females (aged 26-35), Christian women and those living in urban areas on average have a higher chance of identifying gender discrimination as an issue in their country.

Figure 5 illustrates the geographical distribution of the share of women identifying gender discrimination as an issue in each country (averaged over the sample period). The degree of gender discrimination measured in this way varies between 0.01 and 0.80 . Many of the world's worst performers are situated in South America, sub-Saharan Africa and Russia with Dominican Republic, Colombia and Honduras closing the country ranking. Women indicate to be facing much lower discrimination in Europe, North America, Central Asia, the Middle East and some countries in North Africa. The lowest level of gender inequality can be found in the United Arab Emirates, Rwanda and Qatar. ${ }^{9}$

\subsection{Migration and gender discrimination}

Comparing the geographical distributions from the previous sections already offers some preliminary evidence for the interconnection between gender discrimination and migration behavior. Darker colors in Figure 5 are associated with lighter colors in Figure 3, confirming the expected negative relationship between perceived gender discrimination and migration intentions. Comparing Figures 4 and 5, on the other hand, does not reveal a clear pattern.

\footnotetext{
${ }^{9}$ In general, we find a similar ranking as the one based on the SIGI indicator (averaging over 2009 and 2012 values), with a few exceptions. Whereas the SIGI indicator suggests that women are facing relatively high discrimination in social institutions in the Middle East and North Africa, gender discrimination based on individual perceptions in these countries seems much lower. Comparing the lower and upper tails of the distribution of the two indicators, we find no anomalies except for Peru which occupies the sixth best place in the ranking according to SIGI and the fourth worst place based on individual perceptions. Yet, as mentioned before, individual perceptions are not necessarily expected to be in line with objective evaluations of the degree of gender discrimination because the former is influenced by personal characteristics and the respondent's social environment (see e.g. Verloo, 2007).
} 
Figure 5: Aggregate gender discrimination by country (females)

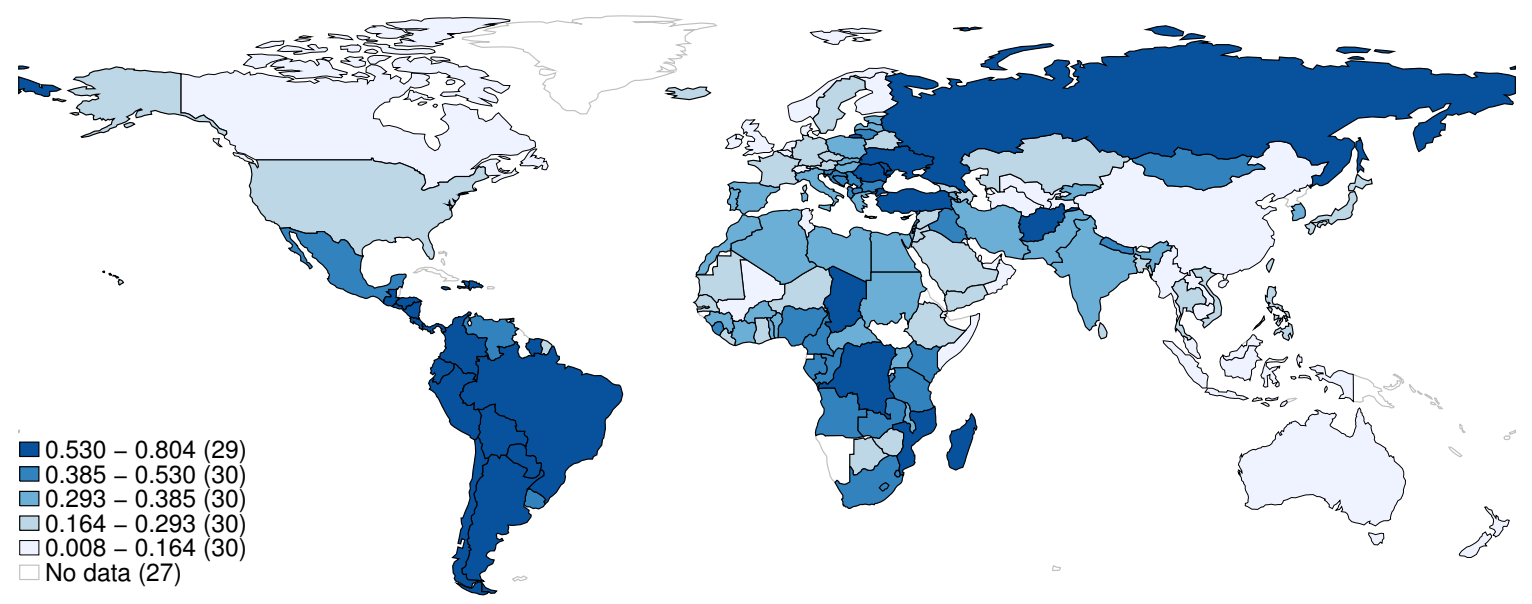

Source: Authors' calculations based on the Gallup World Polls.

This can also be seen from plotting aggregate migration intentions and preparations against the aggregate degree of gender discrimination in a country perceived by its female inhabitants. Figures 6 and 7 reveal that perceived gender discrimination is significantly and positively correlated with migration intentions with a slope of 0.22 , while the correlation with the share of those who already started preparing their move is insignificant.

\subsection{Other descriptives}

Our empirical analysis also takes into account other personal characteristics which might have an impact on migration behavior. They comprise the respondent's current marital status; educational level; employment status; age; the number of children under 15 years of age currently living in the respondent's household; a dummy variable for living in a large city or a suburb of a large city; the log of household income per capita; the household size, a dummy variable for having a household member, a friend or a relative abroad, and finally an index measuring experiential wellbeing. For further details on these variables, see Appendix A.

Table 1 provides summary statistics for the main variables of interest for respondents respectively replying to the questions on migration intentions and preparation. A few observations are worth mentioning. In our sample, 54 percent of the women is married, 
Figure 6: Aggregate perceived gender discrimination and intentions to migrate (females)

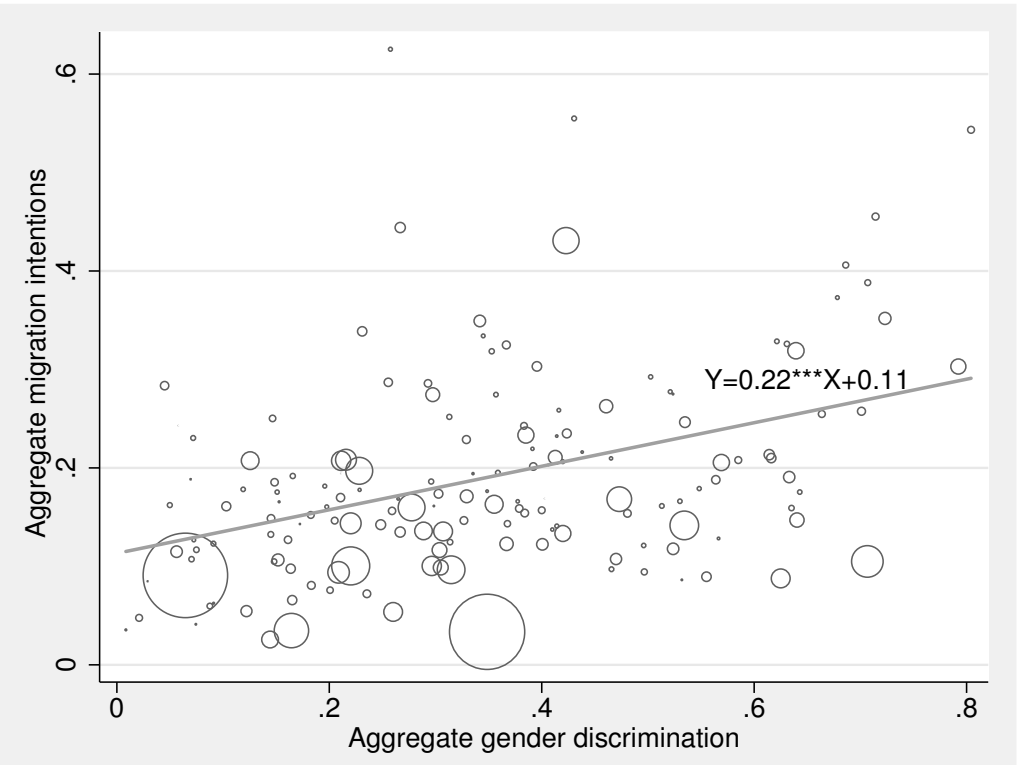

Notes: Authors' calculations based on the Gallup World Polls. Aggregate gender discrimination is calculated as the share of female respondents stating that women in their country are not treated with respect and dignity. Aggregate migration intentions is measured as the share of female respondents claiming that they intend to move abroad when an opportunity arises. The surface of each circle is proportional to the size of the native population residing in each country in 2000 .

41 percent lives in an urban area, 41 percent is employed at the time of the interview and respondents on average have 1.44 children living in the household. Intending migrants are younger and slightly higher educated. Their number of children in the household is slightly higher, i.e. 1.66 , but the most striking difference is related to the network abroad. Whereas on average 33 percent of women intending to migrate state that they have a family member or friend abroad, this figure rises significantly to 49 percent when the sample is reduced to women actually preparing to do so. We may thus expect to find a strong impact of social networks on both migration intentions and further migration behavior (see also Bertoli and Ruyssen, 2016; Docquier et al., 2014). 
Figure 7: Aggregate perceived gender discrimination and preparations to migrate (females)

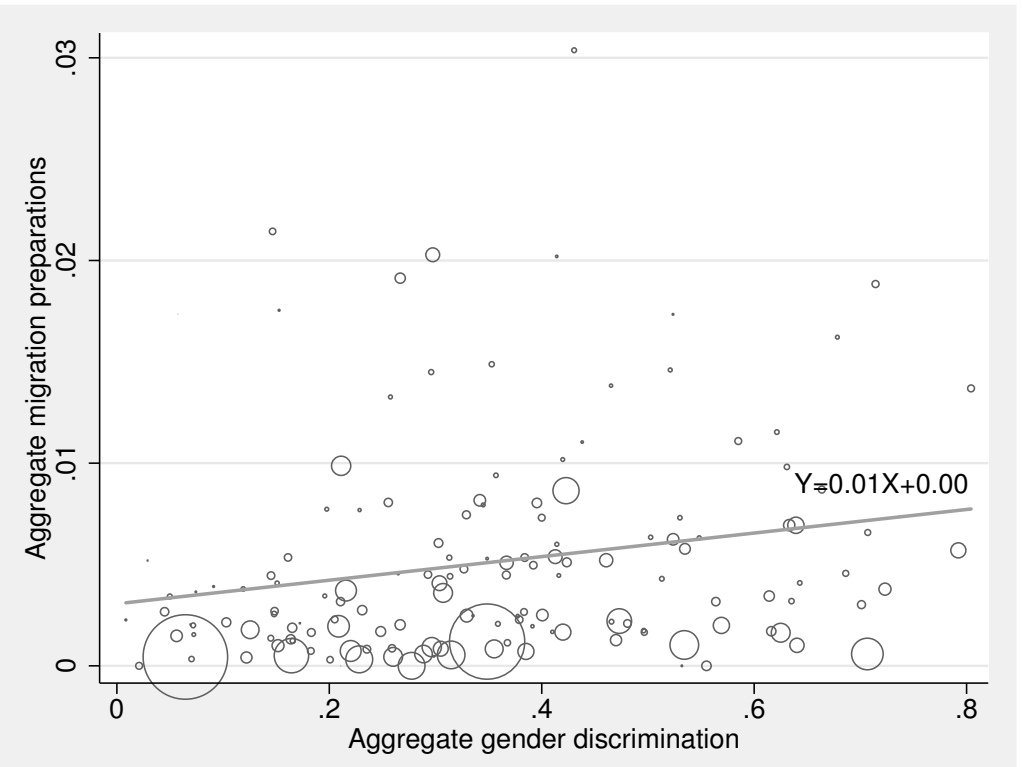

Notes: see Figure 6. Aggregate migration preparations is measured as the share of female respondents intending to migrate who claim that they have started making preparations for their move (e.g. having applied for a residency permit or purchased flight tickets).

\section{Empirical model}

This section describes the empirical framework used to analyze the impact of gender discrimination alongside traditional controls on women's migration behavior. Following Chort (2014), we assume that migration intentions are rational and hence correlated with the same determinants typically found to explain the subsequent migration decision. ${ }^{10}$ Specifically, consider an individual $i$ residing in country $j$, who has to decide whether or not to migrate out of country $j$. Given the cross-country panel nature of our data, we can write the utility that this individual would obtain from migrating out of country $j$ as:

$$
U_{i j}=\alpha+G D_{i j} \beta+X_{i j} \gamma+\delta_{j}+\epsilon_{i j}
$$

\footnotetext{
${ }^{10}$ In general, migration intentions have been shown good predictors of future actual migration suggesting that the factors driving a person's actual migration decision also determine his or her willingness to migrate (Creighton, 2013; Dustmann and Okatenko, 2014; van Dalen and Henkens, 2008).
} 
Table 1: Descriptive statistics (females)

\begin{tabular}{|c|c|c|c|c|c|}
\hline & Observations & Mean & St Dev & Min & $\operatorname{Max}$ \\
\hline \multicolumn{6}{|l|}{ Overall sample } \\
\hline Migration intention & 183353 & 0.195 & 0.396 & 0 & \\
\hline Gender discrimination & 183353 & 0.356 & 0.479 & 0 & 1 \\
\hline Age & 183353 & 39.671 & 17.031 & 15 & 99 \\
\hline Married & 183353 & 0.536 & 0.499 & 0 & 1 \\
\hline High skilled & 183353 & 0.127 & 0.333 & 0 & 1 \\
\hline Number of children & 183353 & 1.436 & 1.860 & 0 & 37 \\
\hline Urban & 183353 & 0.412 & 0.492 & 0 & 1 \\
\hline Employed & 183353 & 0.375 & 0.484 & 0 & 1 \\
\hline Household income pc (log) & 183353 & 7.375 & 1.484 & -5 & 15 \\
\hline Hous & 183353 & 3.251 & 1.891 & 0 & 54 \\
\hline Netw & 18 & 0.339 & 0.473 & 0 & 1 \\
\hline Experiential wellbeing & 183353 & 69.480 & 24.711 & 0 & 100 \\
\hline \multicolumn{6}{|l|}{ Intended migrants } \\
\hline Migration preparc & 8 & 0.039 & 0.195 & 0 & \\
\hline Gender discrimination & 37458 & 0.448 & 0.497 & 0 & 1 \\
\hline Age & 37458 & 32.337 & 13.508 & 15 & 99 \\
\hline Marr & 37458 & 0.441 & 0.497 & 0 & \\
\hline killed & 37458 & 0.148 & 0.356 & 0 & 1 \\
\hline Number of children & 37458 & 1.658 & 1.986 & 0 & 43 \\
\hline Urban & 37458 & 0.449 & 0.497 & 0 & 1 \\
\hline Emp & 37458 & 0.373 & 0.484 & 0 & 1 \\
\hline old income pc (log) & 37458 & 7.162 & 1.447 & -5 & 13 \\
\hline Hou & 37458 & 3.552 & 2.038 & 1 & 54 \\
\hline Network abroad & 37458 & 0.490 & 0.500 & 0 & 1 \\
\hline
\end{tabular}

Source: Authors' calculations based on the Gallup World Polls. The upper panel displays descriptive statistics for all women in our sample while the lower panel corresponds to those who have expressed an intention to move abroad.

where $G D_{i j}$ represents a dummy capturing whether or not individual $i$ indicates that women in country $j$ are treated with respect and dignity. $X_{i j}$ denotes the set of personal and household characteristics traditionally used to explain the individual decision to migrate. Specifically, we include age, marital status (married or not), education level (obtained a college degree or not), number of children in the household, urbanization (urban or rural), employment status, income (log of per capita household income in PPP international dollars) ${ }^{11}$, household size and the presence of a network abroad (having a household member, a friend or a relative abroad). ${ }^{12}$ The country fixed effects, $\delta_{j}$, allow

\footnotetext{
${ }^{11}$ Other authors consider also the role played by perceived income (see e.g. Dustmann and Okatenko, 2014). As a robustness check, we also included satisfaction with the personal standard of living and satisfaction with the household income, but this did not alter our main findings.

${ }^{12}$ For details on the data construction of the variables included in the empirical analysis, see Appendix
} 
to account for unobserved characteristics common to all inhabitants in the country.

The observed dependent variables Intention $_{i j}$ and Preparation $_{i j}$ then take the value 1 if their corresponding utility exceeds 0 , and 0 otherwise. ${ }^{13}$ Assuming that $\epsilon_{i j} \sim N(0,1)$, we can write the empirical specification in the form of a probit sample selection model in which women first identify whether they would be willing to migrate abroad when an opportunity arises, and subsequently - if they intend to move - whether they have actually decided to do so, i.e. started making preparations for their move. The selection and outcome equation take the form:

$$
\begin{aligned}
\text { Intention }_{i j} & =1\left(\alpha_{1}+G D_{i j} \beta_{1}+Z_{i j} \gamma_{1}+\delta_{1, j}+\epsilon_{1, i j}>0\right) \\
\text { Preparation }_{i j} & =1\left(\alpha_{2}+G D_{i j} \beta_{2}+X_{i j} \gamma_{2}+\delta_{2, j}+\epsilon_{2, i j}>0\right)
\end{aligned}
$$

where 1(.) is the indicator function taking the value 1 if the statement in the brackets is true and 0 otherwise. Preparation ${ }_{i j}$ is observed only if Intention $_{i j}=1$, i.e. the probability to prepare for emigration is a conditional probability (conditional to having expressed an intention to emigrate).In other words, the sample in equation (3) is not randomly selected, such that $\rho=\operatorname{Corr}\left(\epsilon_{1, i j} ; \epsilon_{2, i j}\right) \neq 0$. The model is estimated using a Heckman probit approach with country fixed effects, which provides consistent, asymptotically efficient estimates for all the parameters in binary choice models with sample selection (Van de Ven and Van Praag, 1981; Wooldridge, 2010). ${ }^{14}$

In order to have a well identified model, we need an exclusion restriction in the selection equation. If we were to consider migration intentions and preparations as determined by the same set of explanatory variables, the model would be identified only by functional form, in which case Heckman-type coefficients would have no structural interpretation

\section{A.}

${ }^{13}$ Note that the dependent variables are defined unilaterally, i.e. we do not consider the destination dimension. Although it might be interesting to analyze whether gender discrimination differentials determine also women's migration destination choice, this is beyond the scope of the present paper but forms an interesting pathway for future research.

${ }^{14}$ Fixed effects probit models typically produce biased coefficients and standard errors due to the incidental parameter problem. Consistent estimates may, however, be obtained from estimation with country of origin dummies provided that the number of observations per origin country is sufficiently large. This requirement is satisfied in our empirical analysis: the number of observations per origin country in our sample on average amounts to 1256 for migration intentions and 244 for migration preparations. 
(Maddala, 1999). Therefore, we add an index of experiential wellbeing $\left(E B_{i j}\right)$ to the set of explanatory variables in equation (2), i.e. $Z_{i j}=\left\{X_{i j}, E B_{i j}\right\}$. This index combines a set of positive and negative feelings individuals experienced during the day prior to the interview (i.e. whether or not the respondent experienced enjoyment and happiness, liked what she did all day, felt respected, smiled and laughed a lot as well as whether she experienced anger, depression, sadness, stress or worry). In contrast to evaluative wellbeing (i.e. the way people remember their experiences after they are over), experienced wellbeing seeks to bypass the effects of judgment and memory and captures feelings and emotions as close to the subject's immediate experience as possible (Gallup, 2012). We expect that this experienced wellbeing the day before the survey might affect how people reply to the question on migration intentions but it cannot have made them start preparing for their move given the short time frame.

\section{Estimation}

Each specification includes country of origin fixed effects and is fitted using the joint maximum-likelihood procedure Heckman probit, unless stated otherwise. Standard errors are robust to heteroskedasticity and are clustered across origins. In general, the model always converges and the Wald test always rejects the hypothesis that all parameters are jointly zero.

\subsection{Benchmark specification}

Table 2 presents Heckman probit estimates of the impact of gender discrimination and traditional controls on female migration intentions and preparations. The first two columns report estimated coefficients for the model including only personal characteristics traditionally included as controls in the literature. In line with expectations, we find that both migration intentions and preparations are higher for unmarried women who are high skilled and live in urban areas. Furthermore, young women are more likely to intend to move abroad but age does not particularly influence the chance that this intention materializes. Our evidence suggests that migration intentions are higher among women in households with higher per capita income and that a higher per capita income also fosters the realization of those migration intentions: women in wealthier households are both more likely to intend to move abroad and more likely to have undertaken action to do so 
conditional upon having expressed an intention to move abroad. Also the network effect plays a key role in both stages of the migration decision, suggesting that women having friends or family abroad are more likely to intend to migrate and that having a network abroad also facilitates doing so (see also Docquier et al., 2014; Bertoli and Ruyssen, 2016). Migration intentions increase with the size of the household but are not explicitly affected by the number of children in the household. Having more family members - and hence family obligations - seems to act as an additional incentive for women to move abroad. With correlation between the number of children living in the household and the total household size standing at 0.37 , the statistically insignificant impact of the number of children might partly be explained by collinearity. Furthermore, as expected, women indicate a higher intention to migrate when their experiential wellbeing the day before the survey was lower. To test the validity of the exclusion restriction, we separately estimate the selection and outcome equation (to which we add the experiential wellbeing index) using a simple probit estimator with origin dummies. The results (reported in the first column of Table A-1) confirm that the index has a significant impact only on female's migration intentions, and not on preparations. With a few exceptions, the impact of these traditional controls is robust across different specifications. All of them are included in the remaining tables but we do no longer report their estimated coefficients for brevity.

The third and fourth column of Table 2 present our benchmark results, introducing individual perceptions towards gender discrimination. Our estimates suggest that whereas gender discrimination clearly acts as an important incentive to migrate, it does not additionally affect the subsequent decision to actually do so among those who intend to move abroad. ${ }^{15}$ The average marginal effect of gender discrimination on women's migration intention is estimated at 6 percentage points: with gender discrimination changing from 0 to 1 , the predictive margin (i.e. the conditional probability of women's migration intention)

\footnotetext{
${ }^{15}$ As a robustness check, we also account for the respondent's religious beliefs, which might be considered another non-economic determinant of the migration decision. As indicated in the Pew Research Center's latest annual report on global restrictions on relgion, roughly a quarter of the world's countries still struggle with high levels of religious hostilities - which can range from religious discrimination to violence to persecution. Religion might hence act as a push factor for people experiencing religious hositlities, or like with gender discrimination - it might act as an obstacle to actually do so when minorities' rights are restricted. Controlling for religious background does not affect our main results. The results are available upon request.
} 
Table 2: Impact of gender discrimination and traditional controls on female migration

\begin{tabular}{|c|c|c|c|c|}
\hline & \multicolumn{2}{|c|}{ Traditional controls } & \multicolumn{2}{|c|}{ Benchmark model } \\
\hline & Intention & Prepration & Intention & Prepration \\
\hline Gender discrimination & & & $\begin{array}{c}0.244^{* * * *} \\
(16.86)\end{array}$ & $\begin{array}{l}0.045 \\
(1.00)\end{array}$ \\
\hline Age & $\begin{array}{c}-0.021^{* * *} \\
(-27.50)\end{array}$ & $\begin{array}{l}-0.004 \\
(-1.31)\end{array}$ & $\begin{array}{c}-0.021^{* * * *} \\
(-27.17)\end{array}$ & $\begin{array}{l}-0.004 \\
(-1.45)\end{array}$ \\
\hline Married & $\begin{array}{c}-0.137^{* * * *} \\
(-9.38)\end{array}$ & $\begin{array}{c}-0.065^{* * *} \\
(-1.96)\end{array}$ & $\begin{array}{c}-0.133^{* * * *} \\
(-9.16)\end{array}$ & $\begin{array}{c}-0.068^{* * *} \\
(-2.05)\end{array}$ \\
\hline High skilled & $\begin{array}{c}0.138^{* * * *} \\
(7.36)\end{array}$ & $\begin{array}{c}0.284^{* * * *} \\
(7.63)\end{array}$ & $\begin{array}{c}0.137^{* * * *} \\
(7.47)\end{array}$ & $\begin{array}{c}0.287^{* * * * *} \\
(7.78)\end{array}$ \\
\hline Number of children & $\begin{array}{l}0.000 \\
(0.03)\end{array}$ & $\begin{array}{l}-0.006 \\
(-0.67)\end{array}$ & $\begin{array}{l}0.000 \\
(0.08)\end{array}$ & $\begin{array}{l}-0.006 \\
(-0.67)\end{array}$ \\
\hline Urban & $\begin{array}{c}0.175^{* * * *} \\
(11.61)\end{array}$ & $\begin{array}{c}0.077^{* * *} \\
(2.21)\end{array}$ & $\begin{array}{c}0.165^{* * * *} \\
(11.33)\end{array}$ & $\begin{array}{c}0.081^{* * *} \\
(2.33)\end{array}$ \\
\hline Employed & $\begin{array}{l}0.004 \\
(0.29)\end{array}$ & $\begin{array}{l}0.006 \\
(0.18)\end{array}$ & $\begin{array}{l}0.004 \\
(0.29)\end{array}$ & $\begin{array}{l}0.007 \\
(0.20)\end{array}$ \\
\hline Household income pc (log) & $\begin{array}{c}0.018^{* * *} \\
(2.27)\end{array}$ & $\begin{array}{c}0.092^{* * * *} \\
(4.79)\end{array}$ & $\begin{array}{c}0.018^{* * *} \\
(2.18)\end{array}$ & $\begin{array}{c}0.092^{* * * *} \\
\quad(4.79)\end{array}$ \\
\hline Household size & $\begin{array}{c}0.016^{* * * *} \\
(4.10)\end{array}$ & $\begin{array}{c}0.004 \\
(0.44)\end{array}$ & $\begin{array}{c}0.016^{* * * *} \\
(3.89)\end{array}$ & $\begin{array}{c}0.004 \\
(0.48)\end{array}$ \\
\hline Network abroad & $\begin{array}{c}0.413^{* * * *} \\
(26.00)\end{array}$ & $\begin{array}{c}0.703^{* * * *} \\
(13.17)\end{array}$ & $\begin{array}{c}0.413^{* * * *} \\
(26.21)\end{array}$ & $\begin{array}{c}0.713^{* * * * *} \\
(13.79)\end{array}$ \\
\hline Experiential wellbeing & $\begin{array}{c}-0.004^{* * * * *} \\
(-14.54)\end{array}$ & & $\begin{array}{c}-0.004^{* * * * *} \\
(-13.29)\end{array}$ & \\
\hline $\begin{array}{l}\text { Log likelihood } \\
\text { Observations }\end{array}$ & & $\begin{array}{l}79.9 \\
353\end{array}$ & $\begin{array}{r}-82 \\
18\end{array}$ & $\begin{array}{l}20.9 \\
353\end{array}$ \\
\hline
\end{tabular}

Notes: The model includes country of origin dummies (not reported). Standard errors are robust to heteroskedasticity and clustered across origins. $t$ statistics in parentheses.

${ }^{*} p<0.10,{ }^{* *} p<0.05,{ }^{* * *} p<0.01$.

increases from 17.2 to 23.2 percent. Our evidence hence suggests that the proportion of females intending to migrate is 6 percentage points higher for those who consider gender discrimination to be an issue in their country compared to those who indicate not to experience any gender imbalances.

Women's preparation to migrate conditional upon intending to move abroad, on the other hand, is neither enhanced nor constrained by gender discrimination, but rather explained by different personal factors such as household income or having friends or relatives abroad. Nevertheless, this does not mean that gender discrimination does not affect migration preparations. To see this, let us consider the following numerical example. We have that 165 out of 1,000 women in the GWP who do not feel discriminated express an intention to migrate and only 39 (i.e. 23.6 percent) of them actually prepare to do so. If these women suddenly start to experience gender discrimination in their country, their 
conditional probability to intend to migrate would rise by 6 percentage points. Hence, all else held constant, this would translate in an increase in the number of intended female migrants from 165 to 225 . Consequently, also the number of women preparing to move would rise from 39 to 53 (i.e. 23.6 percent of 225). In other words, from a quantitative point of view, a change in the number of women intending to migrate because of gender discrimination also affects the number of women actually preparing to migrate abroad. This is an important point as female emigration from gender-unequal countries has been shown to spur development in both origin and destination countries (see Kenny and O’Donnell, 2016).

\subsection{Addressing potential threats to identification}

Our estimation approach is exposed to threats to identification posed by measurement error concerning our variable of interest as well as omitted variables, i.e. unobserved factors that influence both perceptions of gender discrimination and migration behavior. We follow four distinct and complementary approaches to address the concerns that our evidence about the key role played by perceived gender discrimination in determining female migration intentions stems from measurement error or unobservables. More precisely, we re-estimate the benchmark model (i) on suitably modified samples, (ii) applying an instrumental variables approach, (iii) on matched samples constructed using the Mahalanobis Metric Matching method, and (iv) adding further country-level controls and more disaggregated gendered variables.

\subsubsection{Modified samples}

First of all, endogeneity might arise as a result of measurement error in our explanatory variable of interest. Section 2.2 already provides initial statistical support for the eligibility of our measure of perceived gender discrimination. Yet, several issues remain.

First, we have to ensure that our indicator truly captures gender discrimination rather than a general lack of civil and political rights which would affect men and women in a similar way (see e.g. Meierrieks and Renner, 2017). ${ }^{16}$ As a first robustness check,

\footnotetext{
${ }^{16}$ Note that we do not argue that men are not concerned with gender discrimination issues (see also Ferrant and Tuccio, 2015). At first sight, indeed it seems that granting more rights to women holds no obvious advantages to men. Yet, men are the ones who put all the reforms regarding women's rights in
} 
we therefore replicate our benchmark estimation using the whole sample, i.e. data for both men and women, to which we add a dummy for women and subsequently also an interaction term between this dummy and perceived gender discrimination.

The first column of Table 3 reveals that, after controlling for the traditional set of personal characteristics, women generally have both lower intentions to migrate than men and a lower propensity to realize their migration plans (see also Chort, 2014). The probability that a woman intends (prepares) to migrate compared to a man is 6 (1) percentage points lower. The second column of Table 3 then confirms that both women and men are concerned with gender discrimination when considering to move abroad but the effect is stronger for women than for men. Specifically, gender discrimination raises the conditional probability of intended migration by 6 percentage points for women and by 5 percentage points for men. Yet, for actual migration preparations, again the effect of gender discrimination itself and the interaction term with gender remain insignificant. ${ }^{17}$

A second source of measurement error might stem from the fact that our sample includes not only natives, but also previously arrived immigrants residing in the country. Some of the foreign respondents might however be temporary migrants, who plan to return to their country of origin, or transit migrants who plan to move to another country in the (near) future. Former migrants might be more likely to migrate again and could hence exhibit different migration behavior than natives. In order to test the sensitivity of our

the last centuries in place. Also today's gender composition and agendas of international organisations and lobbies ("promoting gender equality and empowering women" is one of the eight UN Millennium Development Goals) suggest that efforts to improve females' conditions are not only pursued by women (see e.g. Farré, 2011; Scambor et al., 2013). Doepke and Tertilt (2009) attribute men's concern with gender equality to rational incentives rather than moral sentiments. Their argument is that, from a man's perspective, there is a trade-off between the rights of a husband's own wife and the rights of other men's wives.

${ }^{17}$ In order to see whether the impact of gender discrimination on migration behavior depends also on other personal characteristics, we experimented with additional interaction terms. The effect of perceived gender discrimination does not seem to vary with a woman's age, marital status, education level, employment status or the degree of urbanization of her living environment. The only statistically significant interaction term involves per capita household income, and this only for migration intentions. Yet, the pairwise correlation between this interaction term and perceived gender discrimination stands at 0.97 , significant at 1 percent, which explains why perceived gender discrimination is no longer significant once this interaction term is included. The estimation results are reported in Tables A-2 and A-3. 
Table 3: Estimations on modified samples

\begin{tabular}{lccccc}
\hline & Whole sample & Interaction & Natives & Non-Muslim & High skilled \\
\hline Dependent: Migration intentions & & & & \\
Gender discrimination & $0.227^{* * *}$ & $0.190^{* * *}$ & $0.244^{* * *}$ & $0.259^{* * *}$ & $0.294^{* * *}$ \\
& $(16.23)$ & $(11.11)$ & $(16.72)$ & $(15.45)$ & $(10.32)$ \\
Female & $-0.220^{* * *}$ & $-0.244^{* * *}$ & & & \\
Gen discr x Female & $(-11.71)$ & $(-11.67)$ & & & \\
& & $0.069^{* * *}$ & & & \\
& & $(3.84)$ & & & -0.007 \\
Dependent: Migration preparations & 0.004 & 0.028 & 0.056 & -0.005 & $(-0.05)$ \\
Gender discrimination & $(0.16)$ & $(1.01)$ & $(1.21)$ & $(-0.07)$ & \\
Female & $-0.107^{* * *}$ & $-0.083^{* *}$ & & & -12120.9 \\
Gen discr x Female & $(-4.18)$ & $(-2.41)$ & & & 23266 \\
\hline Log likelihood & -166688.8 & -166667.7 & -78498.6 & -50616.8 & 116077 \\
Observations & 341217 & 341217 & 176018 & \\
\hline
\end{tabular}

Notes: The first two columns report estimates obtained using the whole sample of respondents (i.e. women and men), while those reported in the last three columns concern only female respondents. Each model includes country of origin dummies and the same set of individual controls included in the benchmark regression (not reported). Standard errors are robust to heteroskedasticity and clustered across origins. $t$ statistics in parentheses. ${ }^{*} p<0.10,{ }^{* *} p<0.05,{ }^{* * *} p<0.01$.

results to the inclusion of previous migrants, we re-estimate our model excluding them from the sample, hence keeping only respondents who were born in the country. Limiting our sample to natives only does not alter our main findings (see column 3 in Table 3). Perceived gender discrimination always appears as a strong and robust determinant of intended migration but not of subsequent migration behavior.

Third, it could be argued that gender discrimination affects women's freedom of speech. Gender inequality may bias the responses provided during the Gallup interviews. If women's freedom of speech is more restricted than men's because of cultural or religious barriers, as in many Muslim countries $^{18}$, individual replies to the Gallup question on perceived gender discrimination could be biased. Re-estimating our benchmark model limiting the sample to non-Muslim countries only again does not affect our results (see

\footnotetext{
${ }^{18}$ See the 'Freedom of Expression and the Rights for Women' report by the AHA Foundation at www.theAHAfoundation.org.
} 
column 4 in Table 3).

Furthermore, the answer to the GWP question regarding gender discrimination might be influenced by socio-cultural preferences. The cultural transmission of values and norms within the family, for instance, can have important effects on the way women are treated in their country (Escriche et al., 2004) as well as on social norms regarding gender equality. Depending on socio-cultural preferences and traditions, some respondents might claim that their country has reached a non-discriminatory gender balance whereas others living in the same country might still perceive gender discrimination to be an issue (Belotti, 1980). We presume this resilience of beliefs to be lower for the highly educated. As such, their perceptions of gender discrimination should be less dependent on their socioeconomic environment. In order to test whether our empirical analysis suffers from this kind of bias, we limit our sample to high skilled females only, i.e. those who completed at least 4 years of education beyond high school and/or received a 4-year college degree. Column 5 in Table 3 reports a similar effect of gender discrimination on migration intentions of high skilled women compared to that obtained in the benchmark model and again an insignificant effect on migration preparations. Furthermore, although not reported here, it is interesting to see that the migratory behavior of high skilled women is negatively affected by the number of children at the 1 percent significance level.

\subsubsection{IV approach and matched samples}

As discussed above, the estimated effect of perceived gender discrimination might be due also to unobserved variables that are correlated both with our variable of interest and with migration behavior. These might concern both unobserved individual as well as country characteristics. In the previous sections, we already reported several robustness checks controlling for individual omitted variables such as a respondent's religious beliefs as well as satisfaction with the personal standard of living or with the household income, all of which left our main findings unaltered. To uncover the causal effect of perceived gender discrimination on migration intentions and preparations, we apply an instrumental variables (IV) approach. The latter can, however, be conducted only by treating equations (2) and (3) as independent, thereby ignoring potential sample selection bias. As explicitly stated by Wooldridge (2010), allowing for endogeneity in a binary choice model with sample selection is difficult and an integrated approach that simultaneously tackles both issues in such a model does not exist. 
Keeping this in mind, we separately estimate equations (2) and (3) using the special regressor approach proposed by Lewbel (2000). This IV approach accounts for the binary nature of both the dependent variable and gender discrimination, $G D_{i j}$, which is in this case treated as endogenous (Greene, 2003; Wooldridge, 2010). In fact, special regressor based choice probability estimates are consistent with probit models (unlike those based on linear probability models); do not impose assumptions regarding the joint distribution of the error terms $\epsilon_{k, i j}$ and $\epsilon_{k, i j}^{\prime}$ (unlike maximum likelihood estimators); and permit general, unknown forms of heteroskedasticity in the model errors (Dong et al., 2012). The special regressor estimator only requires that the model includes a particular regressor, $V$, which (i) is exogenous (conditionally independent of the error terms), (ii) appears as an additive term in the model, (iii) is continuously distributed with a large support, and (iv) preferably has a thick-tailed distribution. The requirements on the instrument set are then the same as those for the linear two-stage least squares estimator, i.e. instruments should be independent of the error terms and of full rank.

Following Dong and Lewbel (2015) who developed a special regressor estimator to analyze US interstate migration, we re-estimate our benchmark model with age as the special regressor, satisfying all requirements. Specifically, $V_{i j}$ is defined as the negative of age minus its mean to ensure that it has a positive coefficient and a zero mean. As instrumental variable for perceived gender discrimination we use an index for gender marking in the language spoken by the respondents in the GWP, inspired by the recent economic literature on the relation between gender in language and gender biases in labor market, political and managerial outcomes at both individual and country level (Gay et al., 2013, 2014, 2015). ${ }^{19}$ Specifically, we make use of the aggregate Gender Identity Index (GII) constructed by Gay et al. (2014) which exploits information on all grammatical features

\footnotetext{
${ }^{19}$ The rationale for this instrument relates to both cognitive and cultural mechanisms according to which gender marking in language may influence the formation of gender identities, the salience of deviant behavior from gender roles and gender roles themselves. In linguistics, a gender system is a set of rules for agreements that depend on nouns of different types (Gay et al., 2014). The latter can be based on biological sex (female versus male), or based on other social constructs (such as the distinction between human and animal, age, social status). There are languages in which gender is evident in almost every phrase, and others where it is completely absent (Corbett, 2011). This grammatical gender is one of the most stable features of a language grammar, dating back thousands of years (see e.g. Wichmann and Holman, 2009)
} 
directly related to expressions of gender (i.e. four out of the 192 grammatical features classified by Corbett, 2011). For more information on the construction of the index, see Appendix A. To identify the language spoken by respondents in the GWP, we take the language spoken during the interview, assuming that this is either the language commonly used by the respondent or the one spoken at home. ${ }^{20}$

Table A-1 reports the first-stage probit estimation results. The F-test suggests that the Gender Identity Index is a strong instrument of perceived gender discrimination. The reported Wald test shows that, using the whole sample of women, the null hypothesis of no exogeneity of the instrumental variable is rejected at the 1 percent confidence level (first column), confirming the validity of the instrument.

The first and second columns of Table 4 show that re-estimating our model using this IV approach confirms the positive significant effect of gender discrimination on females' migration intentions as well as the lack of an additional impact on the realization of these intentions. ${ }^{21}$ Marginal effects derived from the average index function proposed by Dong et al. (2012) indicate that the predicted probability of intending to migrate is 2.9 percentage points greater for women who signal gender discrimination to be an issue in their country. The estimated marginal effect of perceived gender discrimination for migration preparations stands at -1.2 percentage points but remains insignificant.

As pointed out above, IV strategies can rule out endogeneity concerns, but they assume that both samples in equations (2) and (3) are randomly collected from the underlying population, which we know is not the case. To further mitigate concerns about potential threats to identification while accounting also for sample selection, we can replicate a randomized experiment by creating well-matched samples of female intending migrants

\footnotetext{
${ }^{20}$ This information is available for almost all respondents in the sample of interest with a few exceptions. For those respondents for whom the information is missing, we chose the language of the country of residence that is spoken by at least 80 percent of the national population (this is the case for Germany, Hungary, Iran, Poland, Qatar, Slovenia, Somalia, United Kingdom, United States and Yemen). For respondents residing in countries where no such language exists (i.e. in Benin, Luxembourg, Singapore and South Africa) the information is set to missing.

${ }^{21}$ Note that we assumed that only the mean of age is related to the other covariates but also when we allow higher moments of age to depend on the other covariates, we get similar results. The results are also robust to using the kernel density estimator rather than the sorted data density estimator which we used here. The results for these alternative estimation procedures are available upon request.
} 
Table 4: Instrumental variables approach and Heckman probit on matched samples - Female migration

\begin{tabular}{lccccc}
\hline & \multicolumn{2}{c}{ Special Regressor } & & \multicolumn{2}{c}{ Heckman probit on matched sample } \\
\cline { 2 - 3 } \cline { 5 - 6 } & Intention & Preparation & & Intention & Preparation \\
\hline Gender discrimination & $112.712^{* * *}$ & -19.777 & & $0.248^{* * *}$ & 0.121 \\
& $(3.71)$ & $(-0.50)$ & & $(13.86)$ & $(1.47)$ \\
\hline Log likelihood & \multirow{2}{*}{ Observations } & \multirow{2}{*}{297045} & & -23535.5 \\
& & & & 52492 \\
\hline
\end{tabular}

Notes: Each model includes country of origin dummies and individual controls (not reported). Standard errors are robust to heteroskedasticity and clustered across origins. $t$ statistics in parentheses. ${ }^{*} p<0.10,{ }^{* *} p<0.05,{ }^{* * *} p<0.01$.

and non-migrants with similar covariate distributions. ${ }^{22}$ This allows to separate out the causal effect of perceived gender discrimination from the effect of preexisting differences between intending migrants (i.e. the "treated" group) and non-migrants (i.e. the "control" group). To identify samples of female intending migrants and non-migrants that are balanced in terms of covariates, we use the Mahalanobis Metric Matching technique (see e.g. Imbens and Rubin, 2015). The resulting matched samples account for the panel structure of our data and have an equal number of observations within each country.

Table A-5 describes the covariates distribution in both the original and matched samples. For each covariate, we report the mean, standard deviation as well as the estimated coefficient obtained from regressing each covariate on the dependent variable Intention $_{i j}$ and country of origin dummies, followed by the $p$-value of the Wald test that this coefficient is equal to zero. In the original sample, there are considerable disparities in the distribution of covariates for female intending migrants versus non-migrants: the differences in personal and household characteristics are always statistically different from zero. The matching technique, however, results in a matched sample exhibiting a balanced distribution of covariates. After matching, the only variable along which female intending

\footnotetext{
${ }^{22}$ Close matching on the observed covariates has been shown to also mitigate bias stemming from unobserved covariates that are correlated with the observed individual characteristics (Stuart, 2010). As such, matching on observables implies at least some degree of matching on unobservables, especially when the set of observed characteristics is fairly complete as in our case. Yet, there may still be unobserved differences between the treated and control groups, but this is addressed by including additional individual and country-level controls.
} 
migrants and non-migrants exhibit statistically different outcomes is the household size, and this only at the 10 percent level.

Columns 3 and 4 of Table 4 report Heckman probit estimates obtained using the matched samples, and show that our main results are not driven by disparities in the distribution of covariates: perceived gender discrimination provides an incentive for women to leave their country but it does not additionally affect migration preparations. The estimated marginal effect of perceived gender discrimination stands at 5.8 percentage points which is almost identical to that obtained in our benchmark regression.

\subsubsection{Inclusion of additional controls}

A different way to deal with the threats to identification posed by unobservables is to include additional controls which might simultaneously determine migration behavior and perceptions of gender discrimination in a country. It should be noted that time-invariant unobserved country characteristics influencing both migration behavior and perceived gender discrimination are captured by the country fixed effects. Yet, to further mitigate concerns of joint determination, we re-estimate our benchmark model adding time-varying country characteristics as additional controls, which allow us to control for the quality of institutions, the average living standard and other factors that may affect overall living conditions. Specifically, we include the Polity IV index to proxy for the level of democracy and regime changes. Average living standards are approximated by the log of GDP per capita in purchasing power parities, female life expectancy and HIV prevalence in percent of the population. ${ }^{23}$ The data for these indicators were obtained from the World Development Indicators (2015). Finally, we also consider the log of the occurrence of natural disasters and intrastate conflict, taken respectively from the CRED EM-DAT International Disaster Database and the UCDP Non-State Conflict Database 2.5 (2014). The estimates are reported in Table A-4. In general, our results are robust to the inclusion of these additional country-specific time-varying controls: the positive significant (insignificant) effect of gender discrimination on women's intentions (preparations) to move is preserved. Note that women have a lower intention to migrate from richer coun-

\footnotetext{
${ }^{23}$ We also collected data on female literacy and the yearly number of intentional homicides per 100,000 inhabitants but inclusion of these variables drastically reduced the sample size. Therefore, although their inclusion did not affect our main results, we decided not to report the results (available upon request).
} 
tries with a higher female life expectancy. We also find that those who want to migrate are more likely to effectively undertake action in countries experiencing conflict.

Finally, we also account for the intensity of gender discrimination. It could be argued that gender discrimination exists in all countries (e.g. women earn lower average wages than men worldwide, even after controlling for observed characteristics) and that our individual measure of gender discrimination might capture whether a woman feels discriminated, but not the severity of gender discrimination. It is important to note that time-invariant differences in the intensity of gender discrimination across countries are controlled for through the country fixed effects. Nonetheless, to explicitly account for both dimensions we can add to the benchmark model a time-varying measure of the intensity of discrimination as well as its interaction with individual perceptions of gender discrimination.

In particular, we consider two distinct objective measures of the intensity of gender discrimination in a country, namely the share of female seats in parliament and the gender gap in labor market participation, both taken from the World Development Indicators. The estimated coefficients for the share of female seats in parliament (reported in the first two columns of Table 5) appear negatively significant for migration intentions, but insignificant for migration preparations. Women thus have a lower intention to migrate abroad when women's representation in parliament is higher. The interaction terms remain always insignificant, suggesting that the effect of perceived gender discrimination does not vary with the severity of gender inequalities. Importantly, the estimated effect of individual perceptions of gender discrimination remains unaffected. Replacing the share of female seats in parliament by the country-level gender gap in labor market participation (reported in the third and fourth columns of Table 5) again preserves our main findings but produces no additional significant results. This lack of significance may be due to the fact that identification comes only from changes in the level of gender imbalances over time, which are likely to be limited given the relatively short time frame of our analysis (2009-2013).

More variation can come, however, from a more disaggregate measure of the extent of gender discrimination which can be built using the GWP. Specifically, we compute the gender gap in the labor market participation rates for people at working age (i.e. aged 
25-64) by education level and rural versus urban residence. ${ }^{24}$ Adding to our benchmark specification both the previously significant share of female seats in parliament as well as this more disaggregated gender gap in labor market participation rates along with their interaction with individual perceptions of gender discrimination (reported in the last two columns of Table 5) again does not alter our previous findings ${ }^{25}$ : the estimated coefficient of individual perceptions of gender discrimination remains positive and highly significant for migration intentions and insignificant for migration preparations. Apart from the recurring significant negative effect of women's representation in parliament, neither of the additional terms appear to significantly drive migration intentions. Interestingly, though, we do find a robust negative impact of the gender gap in labor market participation on migration preparations (significant at the 5 percent level). The results for the interaction term between individual perceptions of gender discrimination and gender gaps in labor market participation remains insignificant.

In sum, these findings suggest that perceived gender discrimination acts as a push factor for migration, increasing women's intentions to leave the country, but it does not influence migration preparations further on. Women's migration intentions are also found to be stronger when gender inequalities are more severe. Yet, our evidence suggests that the likelihood that these migration intentions are translated into concrete plans to migrate is lower for women facing larger effective gender gaps (see also Loschmann and Siegel, 2013).

\section{Conclusion}

Despite notable progress in recent years, gender discrimination and violence against women remains prevalent and persistent across the world leading to suboptimal outcomes in terms of economic growth and development (De la Croix and Vander Donckt, 2010; Doepke and Tertilt, 2009; Duflo, 2012; Esteve-Volart, 2008). This paper originally contributes to existing gender studies by shedding light on the role of international migration

\footnotetext{
${ }^{24}$ The results remain unaltered when we compute this gender gap distinguishing only by education level.

${ }^{25}$ The same results are obtained when we add to our benchmark specification only the more disaggregated gender gap in labor market participation and its interaction, ignoring the share of female seats in parliament.
} 
Table 5: Controlling for the intensity of gender discrimination - Female migration

\begin{tabular}{|c|c|c|c|c|c|c|}
\hline & \multicolumn{2}{|c|}{ Fem seats parliament } & \multicolumn{2}{|c|}{ Labor market gap (WB) } & \multicolumn{2}{|c|}{ Labor market gap (GWP) } \\
\hline & Int & Prep & Int & Prep & Int & Prep \\
\hline Gender discrimination & $\begin{array}{c}0.271^{* * *} \\
(8.02)\end{array}$ & $\begin{array}{l}0.057 \\
(0.88)\end{array}$ & $\begin{array}{c}0.270^{* * *} \\
(10.34)\end{array}$ & $\begin{array}{l}0.008 \\
(0.13)\end{array}$ & $\begin{array}{c}0.276^{* * *} \\
(6.30)\end{array}$ & $\begin{array}{l}0.029 \\
(0.33)\end{array}$ \\
\hline Female seats parliament (\%) & $\begin{array}{c}-0.020^{* * *} \\
(-3.29)\end{array}$ & $\begin{array}{l}0.004 \\
(1.02)\end{array}$ & & & $\begin{array}{c}-0.020^{* * *} \\
(-3.28)\end{array}$ & $\begin{array}{l}0.003 \\
(0.80)\end{array}$ \\
\hline Gen discr $x$ Fem seats & $\begin{array}{l}-0.001 \\
(-0.75)\end{array}$ & $\begin{array}{l}-0.001 \\
(-0.18)\end{array}$ & & & $\begin{array}{l}-0.001 \\
(-0.79)\end{array}$ & $\begin{array}{l}-0.000 \\
(-0.03)\end{array}$ \\
\hline Labor market gap (WB) & & & $\begin{array}{l}-0.032 \\
(-0.96)\end{array}$ & $\begin{array}{l}-0.055 \\
(-1.60)\end{array}$ & & \\
\hline Gen discr x LM gap (WB) & & & $\begin{array}{l}-0.001 \\
(-1.16)\end{array}$ & $\begin{array}{l}0.002 \\
(0.92)\end{array}$ & & \\
\hline Labor market gap (GWP) & & & & & $\begin{array}{l}-0.120 \\
(-1.05)\end{array}$ & $\begin{array}{c}-0.404^{* * *} \\
(-1.74)\end{array}$ \\
\hline Gen discr x LM gap (GWP) & & & & & $\begin{array}{l}-0.013 \\
(-0.16)\end{array}$ & $\begin{array}{l}0.144 \\
(0.81)\end{array}$ \\
\hline $\begin{array}{l}\text { Log likelihood } \\
\text { Observations }\end{array}$ & $\begin{aligned}-76 \\
17\end{aligned}$ & & & & & $\begin{array}{l}76.9 \\
760\end{array}$ \\
\hline
\end{tabular}

Notes: The model includes country of origin dummies and individual controls (not reported). Standard errors are robust to heteroskedasticity and clustered across origins. Labor market gap (WB) denotes the country-specific gap between male and female labor market participation taken from the World Bank Indicators; Labor market gap $(G W P)$ denotes the gender gap in labor market participation by origin, education level and rural/urban residence computed from the GWP. $t$ statistics in parentheses. ${ }^{*} p<0.10,{ }^{* *} p<0.05,{ }^{* * *} p<0.01$.

as an additional channel through which gender discrimination can influence developing countries of origin by pushing women abroad.

Mixed results from the recent strand of macro studies related to specific non-economic determinants demonstrate that gender discrimination can act both as an incentive and/or a constraint. Our analysis complements the literature by making use of micro data to evaluate the impact of gender discrimination as perceived by the individual on worldwide international migration behavior. Using unique individual data from the largely unexplored GWP, we exploit information for 148 countries between 2009 and 2013 on women's individual perceptions towards gender discrimination (related to feeling treated with respect and dignity) as well as on their migration intentions and preparations to actually do so. In this way, we are able to track women's intention to migrate as well as the realization of this intention and explore to what extent perceived gender discrimination alongside traditional personal characteristics can foster or impede female migration.

We perform extensive robustness checks, thus mitigating concerns about potential threats to identification posed by measurement error and unobservables. We find that perceived 
gender discrimination forms a strong and highly robust incentive to migrate, but it does not seem to affect subsequent migration behavior. Our evidence suggests that other more traditional determinants such as household income, network effects as well as family obligations subsequently determine whether those intentions are turned into action. Furthermore, women's migration intentions are found to be stronger when gender inequalities are more severe. Finally, we show that the likelihood that migration intentions materializes is lower for women facing more intense gender imbalances in economic and political opportunities.

From an overall development perspective, our findings reveal a complex relationship between gender inequality and the size of potential female migration: gender discrimination is shown to act both as an incentive and an obstacle for women to move abroad. As such, further efforts to reduce gender inequalities are needed to improve the lives of women (as evoked in the Millenium Development Goals) and to empower them to safely pursue their migration intentions, which may in turn form a source of change and development.

\section{Acknowledgements}

We thank Guilhem Cassan, Frédéric Docquier, Gerdie Everaert, Francesco Fasani, Michele Tuccio, an anonymous referee, as well as the participants of the 2016 Workshop on the Economics of Migration, the 2015 Christmas Meeting for Belgian Economist, the 2015 Workshop on Migration Barriers, the 2015 CEMIR Junior Economist Workshop on Migration Research, the Fourth Ghent-Lille Workshop on Economics and the Internal Seminars at IRES, SHERPPA and the University of Antwerp for their useful comments and suggestions. We are also grateful to Robert Manchin and the Gallup Institute for Advanced Behavioral Studies for providing access to the data for the purpose of this project.

\section{References}

Artuç, E., Docquier, F. Özden, C. and C. Parsons (2015). A global assessment of human capital mobility: The role of non-OECD destinations. World Development, 65, 6-26.

Bang, J.T. and A. Mitra (2011). Gender bias and the female brain drain. Applied Economics Letters, 18(9), 829-833.

Baudassé, T. and R. Bazillier (2014). Gender inequality and emigration: Push factor or selection process?. International Economics, 139, 19-47. 
Becerra, D. (2012). The impact of anti-immigration policies and perceived discrimination in the United States on migration intentions among Mexican adolescents. International Migration, 50(4), 20-32.

Behrman, J.R., Foster, A.D., Rosenzweig, M.R. and P. Vashishtha (2014). Women's schooling, home teaching, and economic growth. Journal of Political Economy, 107(4), 682-714.

Belotti, E. (1980). Dalla parte delle bambine. L'influenza dei condizionamenti sociali nella formazione del ruolo femminile nei primi anni di vita. Feltrinelli Edition.

Berhanu, B. and M. White (2000). War, famine, and female migration in Ethiopia, 1960-1989. Economic Development and Cultural Change, 49(1), 91-113.

Bertoli, S. and I. Ruyssen (2016). Networks and migrants' intended destination. IZA Discussion Paper No. 10213.

Black, R., Hilker, L.M. and C. Pooley (2004). Migration and pro-poor policy in East Africa. Working Paper Cry, Sussex Centre for Migration Research.

Cai, R., Esipova, N., Oppenheimer, M. and S. Feng (2014). International migration desires related to subjective wellbeing. IZA Journal of Migration, 3(1), 1-20.

Carling, J. (2002). Migration in the age of involuntary immobility: Theoretical reflections and Cape Verdean experiences. Journal of Ethnic and Migration Studies, 28(1), pp. 5-42.

Chort, I. (2014). Mexican migrants to the US: What do unrealized migration intentions tell us about gender inequalities. World Development, 59, 535-552.

Cingranelli, D.L. and D.L. Richards (2010). The Cingranelli and Richards (CIRI) Human Rights Data Project. Human Rights Quarterly, 32(2), 395-418.

Cingranelli, D.L., Richards, D.L. and K.C. Clay (2014). The CIRI Human Rights Dataset. http://www. humanrightsdata.com, version 2014.04.14.

Cobb-Clark, D. (1993). Immigrant selectivity and wages: The evidence for women. American Economic Review, 83(4), 986-993.

Corbett, G.G. (2011). Number of Genders. In: Dryer, M.S. and Haspelmath, M. (eds.) The World Atlas of Language Structures Online, Max Planck Digital Library.

Cortes, P. (2015). The feminization of international migration and its effects on the children left behind: Evidence from the Philippines. World Development, 65, 62-78.

Creighton, M.J. (2013). The role of aspirations in domestic and international migration. Social Science Journal, 50(1), 79-88.

De Haas, H. (2009). Mobility and Human Development. UNDP Human Development Reports, Research Paper 2009/1.

De la Croix, D. and M. Vander Donckt (2010). Would empowering women initiate the demographic transition in least-developed countries?. Journal of Human Capital, 4(2), 85-129.

Docquier, F., Lowell, B.L. and A. Marfouk (2009). A gendered assessment of highly skilled emigration. Population and Development Review, 35 (2), 297-322.

Docquier, F., Marfouk, A., Salomone, S. and K. Sekkat (2012). Are skilled women more migratory than skilled men?. World Development, 40(2), 251-265.

Docquier, F., Peri, G. and I. Ruyssen (2014). The cross-country determinants of potential and actual migration. International Migration Review, 48(S1), 37-99.

Doepke, M. and M. Tertilt (2017). Does Female Empowerment Promote Economic Development? mimeo. 
Doepke, M., and M. Tertilt (2009). Women's liberation: What's in it for men?. Quarterly Journal of Economics, 124(4), 1541-1591.

Dong, Y., Lewbel, A. and T.T. Yang (2012). Comparing features of convenient estimators for binary choice models with endogenous regressors. Canadian Journal of Economics, 45, 809-829.

Dong, Y. and W. Lewbel (2015). A simple estimator for binary choice models with endogenous regressors. Econometric Reviews, 34(1-2), 82-105.

Duflo, E. (2012). Women empowerment and economic development. Journal of Economic Literature, 50(4), 1051-79.

Duflo, E. and Udry, C. (2004). Intra-household resource allocation in Cote d'Ivoire: Social norms, separate accounts and consumption choices. NBER Working Paper, No. 10498.

Dumont, J.C., Martin, J.P., and G. Spielvogel (2007). Women on the move: The neglected gender dimension of the brain drain. IZA Discussion Paper, No. 2920.

Dustmann, C. and A. Okatenko (2014). Out-migration, wealth constraints, and the quality of local amenities. Journal of Development Economics, 110, 52-63.

Drinkwater, S. and P. Ingram (2009). How different are the British in their willingness to move? Evidence from international social survey data. Regional Studies, 43(2), 287-303.

Escriche, L., Olcina, G. and R. Sanchez (2004). Gender discrimination and intergenerational transmission of preferences. Oxford Economic Papers, 56, 485-511.

Esipova, N., Ray, J. and A. Pugliese (2011). Gallup World Poll: The many faces of global migration. IOM Migration Research Series, No. 43.

Esteve-Volart, B. (2008). Gender discrimination and growth: Theory and evidence from India. SSRN Working Paper Series.

Farré, L. (2011). The Role of Men for Gender Equality. World Development Report 2012, Gender Equality and Development Background Paper.

Ferrant, G. and M. Tuccio, (2015). South-South migration and discrimination against women in social institutions: A two-way relationship. World Development, 72, 240-254.

Friebel, G., Manchin, M. and M. Mendola (2015). Human smuggling and international migration: A cross-country analysis of individual intentions to migrate. Paper presented at the 6th International conference on Economics of Global Interactions: New Perspectives on Trade, Factor Mobility and Development, Bari (Italy), 7-8 September 2015.

Gallup (2012). Worldwide Research Methodology and Codebook, Washington D.C.

Gay, V., Hicks, D., Santacreu-Vasut, E. and A. Shoham (2014). Language and gender economics. Dartmouth College Working Paper, No. 281.

Gay, V., Hicks, D., Santacreu-Vasut, E. and A. Shoham (2015). Decomposing culture: Can gendered language influence women's economic engagement? Fox School of Business Research Paper, No. 15-046.

Gay, V., Santacreu-Vasut, E. and A. Shoham (2013). Do female/male distinctions in language matter? Evidence from gender political quotas. Applied Economics Letters, 20(5), 495-498.

Gray, C.L. and V. Mueller (2012). Drought and population mobility in rural Ethiopia. World Development, 40(1), 134-145.

Gray, C.L. (2011). Soil quality and human migration in Kenya and Uganda. Global Environmental Change, 21, 421-430.

Hatton, T.J. and J.G. Williamson (2002). What fundamentals drive world migration? National Bureau of Economic Research Working Paper, No. 9159. 
Hugo, G.J. (2000). Migration and Women's Empowerment. In: Presser, H.B. and Sen, G. (eds.) Women's Empowerment and Demographic Processes - Moving beyond Cairo, Oxford University Press.

Imbens, G.W., and Rubin, D.B. (2015). Causal Inference in Statistics, Social, and Biomedical Sciences. Cambridge University Press.

Jolly, S., Piper, N. and H. Reeves (2005). Gender and migration: Overview report. Brighton: Institute of Development Studies.

Jonsson, G. (2008). Migration aspirations and immobility in a Malian Soninke villagei, International Migration Institute Working Paper, No. 10-2008, Oxford.

Kenny, C. and M. O'Donnell (2016). Why increasing female migration from gender-unequal countries is a win for everyone. Center for Global Development Notes.

Kofman, E. (2000). The invisibility of skilled female migrants and gender relations in studies of skilled migration in Europe. International Journal of Population Geography, 6(1), 45-59.

Kothari, U. (2002). Migration and Chronic Poverty. University of Manchester Working Paper No. 16., Institute for Development Policy and Management.

Lewbel, A. (2000). Semiparametric qualitative response model estimation with unknown heteroscedasticity or instrumental variables. Journal of Econometrics, 97, 145-177.

Loschmann, C. and M. Siegel (2013). The influence of vulnerability on migration intentions in Afghanistan. UNU-MERIT Working Papers Series, No. 2013-038.

Maddala, G., (1999). Limited-Dependent and Qualitative Variables in Econometrics. Cambridge: Cambridge University Press.

Manchin, M., Manchin, R. and S. Orazbayev (2014), Desire to migrate internationally and locally and the importance of satisfaction with amenities, Paper presented at the FIW-wiiw Seminars in International Economics, 10 April 2014, Austria, Vienna.

Manchin, M. and S. Orazbayev (2016). Social networks and the intention to migrate, Centro Studi Luca d'Agliano Development Studies Working Papers No. 409.

Mbaye, L.M. (2014). "Barcelona or die": Understanding illegal migration from Senegal. IZA Journal of Migration, 3-21.

McFadden, D. (1974). Conditional logit analysis of qualitative choice behavior. in P. Zarembka (ed.), Frontiers in Econometrics, 105-142, Academic Press: New York.

Morrison, A.R., Schiff, M., and M. Sjoblom (2007). The International Migration of Women. Washington: World Bank and Palgrave McMillan.

Nejad, M.N. (2013). Institutionalized inequality and brain drain: An empirical study of the effects of women's rights on the gender gap in high-skilled migration. IZA Discussion Paper, No. 7864 .

Nejad, M.N. and A.Young (2014). Female brain drains and women's rights gaps: A gravity model analysis of bilateral migration flows. IZA Discussion Paper, No. 8067.

Oishi, N. (2002). Gender and migration: An integrative approach. Center for Comparative Immigration Studies Working Paper, No. 49, University of California, San Diego.

Paul, A.M. (2011). Stepwise international migration. A multistage migration pattern for the aspiring migrants. American Journal of Sociology, 116(6), 1842-1886.

Pedraza, S. (1991). Women and migration: The social consequences of gender. Annual Review of Sociology, 17, 303-325. 
Perkins, S.E., Phillips, K.W., and N.A. Pearce (2013). Ethnic diversity, gender, and national leaders. Journal of International Affairs, 67(1), 85-104.

Pew Research Center (2015). Latest trends in religious restrictions and hostilities. Feb. 26, 2015. http://www.pewforum.org/2015/02/26/religious-hostilities/

Ruyssen, I. and S. Salomone (in press). Gender Discrimination as a Driver of Female Migration. In: Timmerman, C., Van Praag, L. and Fonseca, M.L. (eds.) Dynamic Interplays between Gender and Migration, IMISCOE-Springer Series.

Sartori, A.E. (2003). An estimator for some binary-outcome selection models without exclusion restrictions. Political Analysis, 11, 111-138.

Sassen, S. (2003). Globalization and its Discontent. Essays on the New Mobility of People and Money, The New York Press, New York.

Sorensen, N.N. (2004). Migrant transfers as a development tool. Danish Institute for International Studies Policy Paper, No. 16.

Stuart, E. (2010). Matching methods for causal inference: A review and a look forward. Statistical Science, 25(1), 1.

Tuccio, M. and J. Wahba (2015). May I leave the house? Return migration and the transfer of gender norms. IZA Discussion Paper, No. 9216.

United Nations, (2004). Women and migration. Prepared by S.F. Martin. Consultative Meeting on Migration and Mobility and How This Movement Affects Women.

United Nations (2015). Trends in international migrant stock: Migrants by destination and origin, United Nations database: POP/DB/MIG/Stock/Rev.2015.

van Dalen, H.P. and K. Henkens (2008). Emigration intentions: mere words or true plans? Explaining international migration intentions and behavior. Tilburg University Discussion Paper, No. 2008-60.

van Dalen, H.P., Groenewold, G. and T. Fokkema (2005a). The effect of remittances on emigration intentions in Egypt, Morocco, and Turkey. Population Studies, 59(3), 375-392.

van Dalen, H.P., Groenewold, G. and J.J. Schoorl (2005b). Out of Africa: what drives the pressure to emigrate?. Journal of Population Economics, 18(4), 741-778.

Van de Ven, W.P.M.M. and B.M.S. Van Praag (1981). The demand for deductibles in private health insurance: A probit model with sample selection. Journal of Econometrics, 17: 229-252.

Verloo, M. (2007). Multiple Meanings of Gender Equality. A Critical Frame Analysis of Gender Policies in Europe. Budapest, New York: Central European University Press, CPS Books.

Zachariah, K.C., Mathew, E.T. and I. Rajan (2001). Social, economic and demographic consequences of migration on Kerala. International Migration, 39(2), 43-71.

Zlotnik, H. (1990). International migration policies and the status of female migrants. International Migration Review, 24(2), 372-381.

Zlotnik, H. (1995). The South-to-North migration of women. International Migration Review, 29(1), 229-254.

Zlotnik, H. (2003). The global dimensions of female migration. Migration Information. http://www. migrationinformation.org/Feature/display.cfm?ID $=109$.

Wichmann, S. and E.W. Holman (2009). Assessing Temporal Stability for Linguistic Typological Features, Munchen: LINCOM Europa. 


\section{Appendix A. Data construction}

The definition and source of the variables used in the regressions are the following:

Explanatory variables (Source: Gallup World Polls)

- Gender discrimination: dummy for experiencing gender equality. The dummy takes the value 1 when the respondent replies positively to the Gallup question "Do you believe that women in this country are treated with respect and dignity, or not?", and 0 otherwise. This question was asked in 148 countries. ${ }^{26}$

- Married: dummy for current marital status. The dummy takes the value 1 when the respondent is currently married, and 0 when single, widowed, separated, divorced or domestic partner.

- High skilled: dummy for being highly educated, which takes the value 1 when the respondent completed at least 4 years of education beyond high school and/or received a 4-year college degree, and 0 otherwise.

- Children: number of children under 15 years of age currently living in the respondent's household.

- Urban: dummy for living in a large city or a suburb of a large city (as opposed to a rural area, on a farm, a small town or village in which case the dummy takes the value 0 ).

- Employed: dummy for being employed full time for an employer, self-employed or employed part time by choice (as opposed to being employed part time but wanting full time, unemployed or out of the workforce, in which case the dummy takes the value 0 ).

- Household Income per capita: log of household income per capita in PPP international dollars.

- Household size: number of people currently living in the respondent's household.

- Network abroad: dummy for having a household member, a friend or a relative abroad. The dummy combines the replies to two questions of the Gallup database: (i) Have any members of your household gone to live in a foreign country permanently or temporarily in the past five years? (ii) Do you have relatives or friends who are living in another country whom you can count on to help you when you need them, or not? It takes the value 1 if the respondent answered "yes, still there" to the first question (hence, we ignore those who have returned) or "yes" to the second one.

- Age: age of the respondent, varying between 25 and 99 because only those aged $25+$ are considered in our sample.

- Experiential wellbeing index: combines a set of positive and negative feelings individuals experienced during the day prior to the interview, i.e. whether or not the respondent experienced enjoyment and happiness, liked what she did all day, felt respected, smiled and laughed a lot as well as whether she experienced anger, depression, sadness, stress or worry.

\footnotetext{
${ }^{26}$ The country list is the same as the one for migration intentions, except that there are no data on gender discrimination for Liberia and Switzerland.
} 


\section{Instrumental variable}

- Gender Identity Index $G I I \in\{0,1,2,3,4\}$ : corresponds to the sum of the following four individual indices: (i) the Number of Genders Index (NGI) which equals 1 for languages having two genders and 0 otherwise (no gender or more than two genders); (ii) the Sex Based Index (SBI) which equals 1 for languages having a biological sex-based gender system and 0 otherwise; (iii) the Gender Assignment Index (GAI) which equals 1 for languages having both a semantic and a formal gender assignment system and 0 otherwise; and (iv) the Gender Pronouns Index (GPI) which equals 1 for languages with a gender distinction in third-person pronouns and in the first and/or the second person and 0 otherwise. Source: Gay et al. (2014). 


\section{Appendix B. Tables}

Table A-1: Validity of exclusion restriction and instrument - Female migration

\begin{tabular}{|c|c|c|c|c|}
\hline \multirow{2}{*}{$\begin{array}{l}\text { Dependent } \\
\text { Sample }\end{array}$} & \multicolumn{2}{|c|}{$\begin{array}{c}\text { Probit } \\
\text { Migration }\end{array}$} & \multicolumn{2}{|c|}{$\begin{array}{l}\text { Probit IV first stage } \\
\text { Gender discrimination }\end{array}$} \\
\hline & Intention & Preparation & Intention & Preparation \\
\hline Gender discrimination & $\begin{array}{c}0.244^{* * *} \\
(16.86)\end{array}$ & $\begin{array}{l}0.016 \\
(0.52)\end{array}$ & & \\
\hline Age & $\begin{array}{c}-0.021^{* * *} \\
(-27.17)\end{array}$ & $\begin{array}{l}-0.002 \\
(-1.49)\end{array}$ & $\begin{array}{c}-0.001^{* * *} \\
(-15.94)\end{array}$ & $\begin{array}{c}0.002^{* * *} \\
(7.51)\end{array}$ \\
\hline Married & $\begin{array}{c}-0.133^{* * *} \\
(-9.17)\end{array}$ & $\begin{array}{r}-0.053^{*} \\
(-1.78)\end{array}$ & $\begin{array}{c}-0.013^{* * *} \\
(-5.49)\end{array}$ & $\begin{array}{c}-0.022^{* * *} \\
(-3.77)\end{array}$ \\
\hline High skilled & $\begin{array}{c}0.137^{* * *} \\
(7.47)\end{array}$ & $\begin{array}{c}0.273^{* * *} \\
(7.33)\end{array}$ & $\begin{array}{l}0.004 \\
(1.03)\end{array}$ & $\begin{array}{l}-0.001 \\
(-0.17)\end{array}$ \\
\hline Number of children & $\begin{array}{l}0.000 \\
(0.08)\end{array}$ & $\begin{array}{l}-0.006 \\
(-0.67)\end{array}$ & $\begin{array}{l}-0.001 \\
(-1.01)\end{array}$ & $\begin{array}{l}0.000 \\
(0.07)\end{array}$ \\
\hline Urban & $0.165^{* * *}$ & $0.062^{* *}$ & $0.044^{* * *}$ & $0.047^{* * *}$ \\
\hline Employed & $\begin{array}{l}0.004 \\
(0.29)\end{array}$ & $\begin{array}{l}0.005 \\
(0.16)\end{array}$ & $\begin{array}{l}0.001 \\
(0.56)\end{array}$ & $\begin{array}{l}0.003 \\
(0.58)\end{array}$ \\
\hline Household income pc (log) & $\begin{array}{c}0.018^{* *} \\
(2.19)\end{array}$ & $\begin{array}{c}0.091^{* * *} \\
(4.72)\end{array}$ & $\begin{array}{c}0.003^{* *} \\
(2.38)\end{array}$ & $\begin{array}{l}-0.003 \\
(-0.99)\end{array}$ \\
\hline Household size & $\begin{array}{c}0.016^{* * *} \\
(3.89)\end{array}$ & $\begin{array}{l}0.002 \\
(0.26)\end{array}$ & $\begin{array}{c}0.002^{* * *} \\
(2.87)\end{array}$ & $\begin{array}{c}0.001 \\
(0.66)\end{array}$ \\
\hline Network abroad & $\begin{array}{c}0.413^{* * *} \\
(26.21)\end{array}$ & $\begin{array}{c}0.671^{* * *} \\
(15.68)\end{array}$ & $\begin{array}{c}0.008^{* * *} \\
(3.04)\end{array}$ & $\begin{array}{l}-0.004 \\
(-0.78)\end{array}$ \\
\hline Experiential wellbeing & $\begin{array}{c}-0.004^{* * * *} \\
(-13.28)\end{array}$ & $\begin{array}{l}0.000 \\
(0.60)\end{array}$ & $\begin{array}{c}-0.003^{* * *} \\
(-56.50)\end{array}$ & \\
\hline Gender Identity Index & & & $\begin{array}{c}0.013^{* * *} \\
(4.95)\end{array}$ & $\begin{array}{c}0.013^{* *} \\
(2.35)\end{array}$ \\
\hline F-statistic & & & 195.39 & 39.99 \\
\hline Prob $>F$ & & & $(0.000)$ & $(0.000)$ \\
\hline Wald $\mathrm{Chi}^{2}(1)$ & & & 25.16 & 0.95 \\
\hline Prob $>\mathrm{Chi}^{2}$ & & & $(0.000)$ & $(0.330)$ \\
\hline Log likelihood & -77386.8 & -5034.3 & & \\
\hline Observations & 183353 & 34839 & 150554 & 30413 \\
\hline
\end{tabular}

Notes: Each model includes country of origin dummies (not reported). Standard errors are robust to heteroskedasticity and clustered across origins. Wald $\mathrm{Chi}^{2}(1)$ and Prob > $C h i^{2}$ correspond to the Wald test of exogeneity of the the Gender Identity Index, i.e. the instrumental variable. $t$ statistics in parentheses. ${ }^{*} p<0.10,{ }^{* *} p<0.05,{ }^{* * *} p<0.01$. 
Table A-2: Interactions with personal characteristics - Female migration intentions

\begin{tabular}{|c|c|c|c|c|c|c|}
\hline & Age & Married & Highly skilled & Urban & Employed & Income \\
\hline Gender discrimination & $\begin{array}{c}0.198^{* * *} \\
(6.02)\end{array}$ & $\begin{array}{c}0.248^{* * *} \\
(13.92)\end{array}$ & $\begin{array}{c}0.198^{* * *} \\
(5.39)\end{array}$ & $\begin{array}{c}0.236^{* * *} \\
(13.71)\end{array}$ & $\begin{array}{c}0.242^{\text {**** }}(13.81)\end{array}$ & $\begin{array}{c}0.054 \\
(0.90)\end{array}$ \\
\hline Age & $-0.021^{* * *}$ & $-0.021^{* * *}$ & $-0.021^{* * *}$ & $-0.021^{* * *}$ & $-0.021^{* * *}$ & $-0.021^{* * *}$ \\
\hline Married & $\begin{array}{c}(-24.52) \\
-0.132^{* * *} \\
(-9.16)\end{array}$ & $\begin{array}{c}(-27.19) \\
-0.129^{* * *} \\
(-8.50)\end{array}$ & $\begin{array}{c}(-27.16) \\
-0.132^{* * *} \\
(-9.14)\end{array}$ & $\begin{array}{c}(-27.18) \\
-0.133^{* * *} \\
(-9.15)\end{array}$ & $\begin{array}{c}(-27.16) \\
-0.133^{* * *} \\
(-9.13)\end{array}$ & $\begin{array}{c}(-27.13) \\
-0.132^{* * *} \\
(-9.14)\end{array}$ \\
\hline High skilled & $0.137^{* * *}$ & $\begin{array}{c}0.137^{* * *} \\
(7.47)\end{array}$ & $\begin{array}{c}\left(-121^{* * *}\right. \\
(5.48)\end{array}$ & $0.137^{* * *}$ & $0.137^{* * *}$ & $0.138^{* * *}$ \\
\hline Number of children & $\begin{array}{l}0.000 \\
(0.10)\end{array}$ & $\begin{array}{l}0.000 \\
(0.08)\end{array}$ & $\begin{array}{l}0.000 \\
(0.08)\end{array}$ & $\begin{array}{l}0.000 \\
(0.08)\end{array}$ & $\begin{array}{l}0.000 \\
(0.08)\end{array}$ & $\begin{array}{l}0.000 \\
(0.06)\end{array}$ \\
\hline Urban & $\begin{array}{c}0.165^{* * *} \\
(11.32)\end{array}$ & $\begin{array}{c}0.165^{* * *} \\
(11.33)\end{array}$ & $\begin{array}{c}0.166^{* * *} \\
(11.34)\end{array}$ & $\begin{array}{c}0.158^{* * *} \\
(8.99)\end{array}$ & $\begin{array}{c}0.165^{* * *} \\
(11.32)\end{array}$ & $\begin{array}{c}0.166^{* * *} \\
(11.33)\end{array}$ \\
\hline Employed & $\begin{array}{l}0.004 \\
(0.30)\end{array}$ & $\begin{array}{l}0.004 \\
(0.29)\end{array}$ & $\begin{array}{l}0.004 \\
(0.30)\end{array}$ & $\begin{array}{l}0.004 \\
(0.29)\end{array}$ & $\begin{array}{l}0.003 \\
(0.17)\end{array}$ & $\begin{array}{l}0.004 \\
(0.30)\end{array}$ \\
\hline Household income pc (log) & $\begin{array}{c}0.017^{* *} \\
(2.18)\end{array}$ & $\begin{array}{c}0.018^{* *} \\
(2.19)\end{array}$ & $\begin{array}{c}0.017^{* *} \\
(2.18)\end{array}$ & $\begin{array}{c}0.018^{* *} \\
(2.19)\end{array}$ & $\begin{array}{c}0.018^{* *} \\
(2.18)\end{array}$ & $\begin{array}{l}0.007 \\
(0.78)\end{array}$ \\
\hline Household size & $\begin{array}{c}0.016^{* * *} \\
(3.89)\end{array}$ & $\begin{array}{c}0.016^{* * *} \\
(3.89)\end{array}$ & $\begin{array}{c}0.016^{* * *} \\
(3.89)\end{array}$ & $\begin{array}{c}0.016^{* * *} \\
(3.89)\end{array}$ & $\begin{array}{c}0.016^{* * *} \\
(3.89)\end{array}$ & $\begin{array}{c}0.016^{* * *} \\
(3.93)\end{array}$ \\
\hline Network abroad & $\begin{array}{c}0.413^{* * *} \\
(26.20)\end{array}$ & $\begin{array}{c}0.413^{* * *} \\
(26.21)\end{array}$ & $\begin{array}{c}0.413^{* * *} \\
(26.20)\end{array}$ & $\begin{array}{c}0.413^{* * *} \\
(26.20)\end{array}$ & $\begin{array}{c}0.413^{* * *} \\
(26.22)\end{array}$ & $\begin{array}{c}0.413^{* * *} \\
(26.21)\end{array}$ \\
\hline Experiential wellbeing & $\begin{array}{c}-0.004^{* * *} \\
(-13.28)\end{array}$ & $\begin{array}{c}-0.004^{* * * *} \\
(-13.29)\end{array}$ & $\begin{array}{c}-0.004^{* * * *} \\
(-13.30)\end{array}$ & $\begin{array}{c}-0.004^{* * * *} \\
(-13.29)\end{array}$ & $\begin{array}{c}-0.004^{* * *} \\
(-13.29)\end{array}$ & $\begin{array}{r}-0.004^{* * * *} \\
(-13.27)\end{array}$ \\
\hline Gen discr x Age & $\begin{array}{l}0.001 \\
(1.61)\end{array}$ & & & & & \\
\hline Gen discr x Married & & $\begin{array}{l}-0.009 \\
(-0.48)\end{array}$ & & & & \\
\hline Gen discr $\mathrm{x}$ Educ & & & $\begin{array}{c}0.040 \\
(1.41)\end{array}$ & & & \\
\hline Gen discr x Urban & & & & $\begin{array}{l}0.019 \\
(0.92)\end{array}$ & & \\
\hline Gen discr $\times$ Empl & & & & & $\begin{array}{l}0.003 \\
(0.17)\end{array}$ & \\
\hline Gen discr $x \mathrm{HH}$ inc $\mathrm{pc}$ & & & & & & $\begin{array}{c}0.026^{* * *} \\
(3.32)\end{array}$ \\
\hline Log likelihood & -82416 & -82420.7 & -82419.1 & -82420.1 & -82420.6 & -82408.3 \\
\hline & 1833 & 183 & 183 & 183353 & 183 & 183353 \\
\hline
\end{tabular}

Notes: The model includes country of origin dummies (not reported). Standard errors are robust to heteroskedasticity and clustered across origins. $t$ statistics in parentheses. ${ }^{*} p<0.10,{ }^{* *} p<0.05$, *** $p<0.01$ 
Table A-3: Interactions with personal characteristics - Female migration preparations

\begin{tabular}{|c|c|c|c|c|c|c|}
\hline & Age & Married & Highly skilled & Urban & Employed & Income \\
\hline Gender discrimination & $\begin{array}{c}0.132^{* *} \\
(2.10)\end{array}$ & $\begin{array}{l}0.053 \\
(1.11)\end{array}$ & $\begin{array}{l}0.071 \\
(0.76)\end{array}$ & $\begin{array}{l}0.058 \\
(1.15)\end{array}$ & $\begin{array}{l}0.062 \\
(1.23)\end{array}$ & $\begin{array}{l}-0.041 \\
(-0.28)\end{array}$ \\
\hline Age & -0.003 & -0.004 & -0.004 & -0.004 & -0.004 & -0.005 \\
\hline Married & $-0.066^{* *}$ & $\begin{array}{l}(-1.44) \\
-0.059 \\
(-133)\end{array}$ & $\begin{array}{l}(-1.40) \\
-0.068^{* *}\end{array}$ & $\begin{array}{l}(-1.45) \\
-0.068^{* *} \\
(-2.06)\end{array}$ & $-0.068^{* *}$ & $-0.069^{* *}$ \\
\hline High skilled & $\begin{array}{c}(-1.98) \\
0.284^{* * *} \\
(7.54)\end{array}$ & $\begin{array}{c}(-1.33) \\
0.286^{* * *} \\
(7.75)\end{array}$ & $\begin{array}{c}(-2.06) \\
0.297^{* * *} \\
(6.10)\end{array}$ & $\begin{array}{c}(-2.00) \\
0.287^{* * *} \\
(7.77)\end{array}$ & $\begin{array}{c}(-2.06) \\
0.286^{* * *} \\
(7.76)\end{array}$ & $\begin{array}{c}0.287^{* * * *} \\
(7.81)\end{array}$ \\
\hline Number of children & $\begin{array}{l}-0.006 \\
(-0.67)\end{array}$ & $\begin{array}{l}-0.006 \\
(-0.67)\end{array}$ & $\begin{array}{l}-0.006 \\
(-0.67)\end{array}$ & $\begin{array}{l}-0.006 \\
(-0.67)\end{array}$ & $\begin{array}{l}-0.006 \\
(-0.65)\end{array}$ & $\begin{array}{l}-0.006 \\
(-0.68)\end{array}$ \\
\hline Urban & $\begin{array}{c}0.078^{* *} \\
(2.25)\end{array}$ & $\begin{array}{c}0.080^{* *} \\
(2.32)\end{array}$ & $\begin{array}{c}0.081^{* *} \\
(2.34)\end{array}$ & $\begin{array}{c}0.093^{* *} \\
(2.34)\end{array}$ & $\begin{array}{c}0.081^{* *} \\
(2.33)\end{array}$ & $\begin{array}{c}0.082^{* *} \\
(2.36)\end{array}$ \\
\hline Employed & $\begin{array}{l}0.006 \\
(0.17)\end{array}$ & $\begin{array}{c}0.006 \\
(0.19)\end{array}$ & $\begin{array}{l}0.006 \\
(0.20)\end{array}$ & $\begin{array}{l}0.007 \\
(0.20)\end{array}$ & $\begin{array}{l}0.027 \\
(0.57)\end{array}$ & $\begin{array}{l}0.007 \\
(0.21)\end{array}$ \\
\hline Household income pc (log) & $\begin{array}{c}0.092^{* * *} \\
(4.79)\end{array}$ & $\begin{array}{c}0.092^{* * *} \\
(4.80)\end{array}$ & $\begin{array}{c}0.092^{* * *} \\
(4.79)\end{array}$ & $\begin{array}{c}0.092^{* * *} \\
(4.78)\end{array}$ & $\begin{array}{c}0.092^{* * *} \\
(4.79)\end{array}$ & $\begin{array}{c}0.086^{* * *} \\
(3.83)\end{array}$ \\
\hline Household size & $\begin{array}{c}0.003 \\
(0.43)\end{array}$ & $\begin{array}{c}0.004 \\
(0.48)\end{array}$ & $\begin{array}{r}0.004 \\
(0.48)\end{array}$ & $\begin{array}{c}0.004 \\
(0.48)\end{array}$ & $\begin{array}{l}0.004 \\
(0.47)\end{array}$ & $\begin{array}{c}0.004 \\
(0.49)\end{array}$ \\
\hline Network abroad & $\begin{array}{c}0.706^{* * *} \\
(13.16)\end{array}$ & $\begin{array}{c}0.712^{* * *} \\
(13.76)\end{array}$ & $\begin{array}{c}0.714^{* * *} \\
(13.89)\end{array}$ & $\begin{array}{c}0.714^{* * *} \\
(13.80)\end{array}$ & $\begin{array}{c}0.713^{* * *} \\
(13.75)\end{array}$ & $\begin{array}{c}0.715^{* * *} \\
(13.88)\end{array}$ \\
\hline Gen discr x Age & $\begin{array}{l}-0.003 \\
(-1.57)\end{array}$ & & & & & \\
\hline Gen discr x Married & & $\begin{array}{l}-0.020 \\
(-0.36)\end{array}$ & & & & \\
\hline Gen discr $\mathrm{x}$ Educ & & & $\begin{array}{l}-0.020 \\
(-0.27)\end{array}$ & & & \\
\hline Gen discr $\mathrm{x}$ Urban & & & & $\begin{array}{l}-0.025 \\
(-0.50)\end{array}$ & & \\
\hline Gen discr x Empl & & & & & $\begin{array}{l}-0.044 \\
(-0.67)\end{array}$ & \\
\hline Gen discr $\mathrm{x} H \mathrm{HH}$ inc $\mathrm{pc}$ & & & & & & $\begin{array}{l}0.012 \\
(0.58) \\
\end{array}$ \\
\hline $\begin{array}{l}\text { Log likelihood } \\
\text { Observations }\end{array}$ & $\begin{array}{c}-82416.4 \\
183353\end{array}$ & $\begin{array}{c}-82420.7 \\
183353\end{array}$ & $\begin{array}{c}-82419.1 \\
183353\end{array}$ & $\begin{array}{c}-82420.1 \\
183353\end{array}$ & $\begin{array}{c}-82420.6 \\
183353\end{array}$ & $\begin{array}{c}-82408.3 \\
183353\end{array}$ \\
\hline
\end{tabular}

Notes: The model includes country of origin dummies (not reported). Standard errors are robust to heteroskedasticity and clustered across origins. The positive significant effect of perceived gender discrimination on migration preparations in the first column stems from the high collinearity between perceived gender discrimination and its interaction with age, for which the pairwise correlation stands at 88 percent. $t$ statistics in parentheses. ${ }^{*} p<0.10,{ }^{* *} p<0.05,{ }^{* * *} p<0.01$. 
Table A-4: Controlling for country characteristics - Female migration

\begin{tabular}{|c|c|c|c|c|c|c|c|c|}
\hline & \multicolumn{2}{|c|}{ Institutions } & \multicolumn{2}{|c|}{ Living standard } & \multicolumn{2}{|c|}{ Disaster } & \multicolumn{2}{|c|}{ Conflict } \\
\hline & Int & Prep & Int & Prep & Int & Prep & Int & Prep \\
\hline Gender discrimination & $0.245^{* * *}$ & 0.052 & $0.227^{* * *}$ & 0.064 & $0.243^{* * *}$ & 0.055 & $0.242^{* * *}$ & 0.054 \\
\hline Age & $\begin{array}{r}(16.87) \\
-0.021^{* * * *} \\
(-2627)\end{array}$ & $\begin{array}{c}(1.15) \\
-0.005^{* * *} \\
(-166)\end{array}$ & $\begin{aligned} & (12.26) \\
-0.021^{* * * *} & (-2606)\end{aligned}$ & $\begin{array}{c}(1.31) \\
-0.007^{* *} \\
(-233)\end{array}$ & $\begin{array}{r}(16.42) \\
-0.021^{* * *} \\
(-2628)\end{array}$ & $\begin{array}{l}(1.19) \\
-0.005\end{array}$ & $\begin{array}{c}(16.29) \\
-0.021^{* * *} \\
(-2634)\end{array}$ & $\begin{array}{c}(1.20)^{* * *} \\
-0.005^{* *}\end{array}$ \\
\hline Married & $-0.136^{* * *}$ & $-0.097^{* * *}$ & $-0.131^{* * *}$ & $-0.063^{* * *}$ & $-0.136^{* * *}$ & $-0.084^{* *}$ & $-0.134^{* * *}$ & $-0.078^{* *}$ \\
\hline High skilled & $0.139^{* * * *}$ & $0.281^{* * * *}$ & $0.146^{* * *}$ & $0.323^{* * *}$ & $0.135^{* * *}$ & $0.285^{* * *}$ & $0.138^{* * *}$ & $0.284^{* * * *}$ \\
\hline Number of children & $\begin{array}{l}0.001 \\
(0.24)\end{array}$ & $\begin{array}{l}-0.006 \\
(-0.66)\end{array}$ & -0.001 & $\begin{array}{l}0.000 \\
(0.05)\end{array}$ & $\begin{array}{l}0.001 \\
(0.23)\end{array}$ & $\begin{array}{l}-0.007 \\
(-0.74)\end{array}$ & $\begin{array}{r}0.000 \\
(0.09)\end{array}$ & $\begin{array}{l}-0.008 \\
(-0.80)\end{array}$ \\
\hline Urban & $0.170^{* * *}$ & $0.084^{* *}$ & $0.182^{* * * *}$ & $0.100^{* * *}$ & $0.170^{* * *}$ & $0.083^{* *}$ & $0.169^{* * *}$ & $0.084^{* *}$ \\
\hline Employed & $\begin{array}{c}(11.49) \\
0.004 \\
(0.30)\end{array}$ & $\begin{array}{c}(2.41) \\
0.021 \\
(0.66)\end{array}$ & $\begin{array}{l}(9.15) \\
0.015 \\
(0.81)\end{array}$ & $\begin{array}{c}(2.92) \\
0.045 \\
(1.20)\end{array}$ & $\begin{array}{l}(11.57) \\
0.006 \\
(0.41)\end{array}$ & $\begin{array}{l}(2.44) \\
0.016 \\
(0.50)\end{array}$ & $\begin{array}{l}(11.51) \\
0.007 \\
(0.46)\end{array}$ & $\begin{array}{c}(2.52) \\
0.019 \\
(0.58)\end{array}$ \\
\hline Household income pc (log) & $\begin{array}{c}0.024^{* * *} \\
(3.48)\end{array}$ & $\begin{array}{c}0.098^{* * *} \\
(4.93)\end{array}$ & $\begin{array}{c}0.025^{* * *} \\
(3.55)\end{array}$ & $\begin{array}{c}0.095^{* * *} \\
(4.31)\end{array}$ & $\begin{array}{c}0.023^{* * *} \\
(3.37)\end{array}$ & $\begin{array}{c}0.098^{* * *} \\
(4.95)\end{array}$ & $\begin{array}{c}0.023^{* * *} \\
(3.42)\end{array}$ & $\begin{array}{c}0.097^{* * *} \\
(4.96)\end{array}$ \\
\hline Household size & $\begin{array}{c}0.018^{* * *} \\
(4.83)\end{array}$ & $\begin{array}{l}0.006 \\
(0.68)\end{array}$ & $\begin{array}{c}0.016^{* * * *} \\
(3.61)\end{array}$ & $\begin{array}{l}0.012 \\
(1.47)\end{array}$ & $\begin{array}{c}0.017^{* * * *} \\
(4.07)\end{array}$ & $\begin{array}{l}0.006 \\
(0.71)\end{array}$ & $\begin{array}{c}0.016^{* * *} \\
(3.84)\end{array}$ & $\begin{array}{l}0.004 \\
(0.52)\end{array}$ \\
\hline Network abroad & $\begin{array}{c}0.418^{* * *} \\
(25.24)\end{array}$ & $\begin{array}{c}0.732^{\text {**** }}(14.28)\end{array}$ & $\begin{array}{c}0.406^{* * * *} \\
(21.74)\end{array}$ & $\begin{array}{c}0.775^{* * *} \\
(14.66)\end{array}$ & $\begin{array}{c}0.417^{* * *} \\
(25.63)\end{array}$ & $\begin{array}{c}0.725^{* * *} \\
(14.45)\end{array}$ & $\begin{array}{c}0.417^{* * *} \\
(25.68)\end{array}$ & $\begin{array}{c}0.717^{* * *} \\
(14.15)\end{array}$ \\
\hline Experiential wellbeing & $\begin{array}{c}-0.004^{* * *} \\
(-13.24)\end{array}$ & & $\begin{array}{c}-0.003^{* * * *} \\
(-9.82)\end{array}$ & & $\begin{array}{c}-0.004^{* * *} \\
(-12.88)\end{array}$ & & $\begin{array}{c}-0.004^{* * *} \\
(-12.94)\end{array}$ & \\
\hline Polity IV & $\begin{array}{l}-0.024 \\
(-1.17)\end{array}$ & $\begin{array}{c}0.021 \\
(0.73)\end{array}$ & & & & & & \\
\hline GDP per capita PPP (log) & & & $\begin{array}{c}-2.212^{* * *} \\
(-3.26)\end{array}$ & $\begin{array}{l}1.781 \\
(1.46)\end{array}$ & & & & \\
\hline Female life expectancy & & & $\begin{array}{c}-0.182^{* * *} \\
(-3.08)\end{array}$ & $\begin{array}{l}0.022 \\
(0.22)\end{array}$ & & & & \\
\hline HIV prevalence $(\%)$ & & & -0.124 & $\begin{array}{l}-0.716 \\
(-162)\end{array}$ & & & & \\
\hline Natural disasters (log) & & & & & 0.058 & -0.041 & & \\
\hline Conflict occurrence (log) & & & & & & & $\begin{array}{l}0.135 \\
(0.98)\end{array}$ & $\begin{array}{c}0.209^{* *} \\
(2.31)\end{array}$ \\
\hline $\begin{array}{l}\text { Log likelihood } \\
\text { Observations }\end{array}$ & $\begin{array}{r}-76 \\
17\end{array}$ & $\begin{array}{l}9.5 \\
13\end{array}$ & $\begin{array}{r}-536 \\
112\end{array}$ & 88.7 & $\begin{array}{r}-78 \\
17\end{array}$ & $\begin{array}{l}358.0 \\
246\end{array}$ & $\begin{array}{r}-79 \\
17\end{array}$ & $\begin{array}{l}591.9 \\
7536\end{array}$ \\
\hline
\end{tabular}

Notes: The model includes country of origin dummies (not reported). Standard errors are robust to heteroskedasticity and clustered across origins. $t$ statistics in parentheses. ${ }^{*} p<0.10,{ }^{* *} p<0.05,{ }^{* * *}$ $p<0.01$. 
Table A-5: Balance checks for original versus matched samples of female intending migrants and nonmigrants

\begin{tabular}{|c|c|c|c|c|c|c|c|c|}
\hline & \multicolumn{4}{|c|}{ Original sample } & \multicolumn{4}{|c|}{ Matched sample } \\
\hline & \multirow[b]{2}{*}{ Mean } & \multirow[b]{2}{*}{ St Dev } & \multicolumn{2}{|c|}{ Test H0: Diff $=0$} & \multirow[b]{2}{*}{ Mean } & \multirow[b]{2}{*}{ St Dev } & \multicolumn{2}{|c|}{ Test H0: Diff $=0$} \\
\hline & & & Coef & P-val & & & Coef & P-val \\
\hline Age & 39.671 & 17.031 & -8.247 & 0.000 & 39.943 & 17.186 & -0.032 & 0.781 \\
\hline Married & 0.536 & 0.499 & -0.100 & 0.000 & 0.532 & 0.499 & 0.000 & 0.913 \\
\hline High skilled & 1.127 & 0.333 & 0.042 & 0.000 & 1.131 & 0.337 & 0.000 & 0.927 \\
\hline Number of children & 1.436 & 1.860 & 0.022 & 0.019 & 1.378 & 1.793 & 0.021 & 0.142 \\
\hline Urban & 0.412 & 0.492 & 0.077 & 0.000 & 0.423 & 0.494 & 0.000 & 0.969 \\
\hline Employed & 0.375 & 0.484 & 0.012 & 0.000 & 0.375 & 0.484 & 0.000 & 1.000 \\
\hline Household income pc & 7.375 & 1.484 & 0.062 & 0.000 & 7.414 & 1.476 & -0.008 & 0.349 \\
\hline Household size & 3.251 & 1.891 & 0.174 & 0.000 & 3.211 & 1.858 & 0.029 & 0.051 \\
\hline Network abroad & 0.339 & 0.473 & 0.164 & 0.000 & 0.343 & 0.475 & 0.002 & 0.708 \\
\hline
\end{tabular}

Notes: The total number of observations in the matched sample stands at 52492. Columns 3 and 7 report the estimated coefficient from a linear regression of the covariate on Intention $_{i j}$ and country of origin dummies to account for the panel structure of the data. Columns 4 and 8 report the p-value from the Wald test that the estimated coefficient is equal to zero. 